Accepted version of manuscript 02 May 2019

\title{
Behaviour of discrete piles used to stabilise a tree-covered railway embankment
}

Smethurst J A, Bicocchi N, Powrie W, O’Brien A S

Joel Andrew Smethurst, BEng PhD GMICE

Associate Professor in Geotechnical Engineering

Faculty of Engineering and Environment

University of Southampton

Southampton. SO17 1BJ.

T: 02380598454

E: jas@soton.ac.uk

Nicola Bicocchi, PhD

Geotechnical Observations Limited

The Peter Vaughan Building

9 Avro Way, Brooklands

Weybridge, Surrey KT13 0YF

T: 01932352040

E: nicola.bicocchi@geo-observations.com

Prof. William Powrie, FREng MA MSc PhD CEng FICE

Dean of Engineering and Environment and Professor of Geotechnical Engineering

Faculty of Engineering and Environment

University of Southampton

Southampton. SO17 1BJ

T: 02380593214

E:wp@soton.ac.uk

Prof. Anthony O’Brien, BSc MSc DIC CEng FICE

Divisional Director, Mott MacDonald

Visiting Professor at the University of Southampton

Mott MacDonald House

8-10 Sydenham Road

Croydon. CR0 2EE

T: 02087742612

E: anthony.obrien@mottmac.com

Word count: 5944 (not including abstract, appendix, references).

Tables: 6

Figures: 18

Keywords: Embankments, Monitoring, Slopes 


\title{
Behaviour of discrete piles used to stabilise a tree-covered railway embankment
}

Smethurst J A, Bicocchi N, Powrie W, O’Brien A S

\begin{abstract}
Many clay railway embankments in the UK are well over 100 years old, and now suffer from a range of stability and serviceability problems. A common means of remediating earthworks that have either suffered, or are assessed as being at risk of, deep-seated slope failure is to install a row of discrete piles along the mid-slope. This paper presents field data from a $9 \mathrm{~m}$ high, pilestabilised embankment at Mill Hill, north London. Initial pore water pressure measurements had shown that the trees present on the earthwork maintained low pore water pressures during winter; thus the trees were left in place after piling to aid stability. The piles initially bent upslope, as a result of inward shrinkage of the embankment over a period of dry weather, before then being loaded by shallower downslope movements of the clay. Later cycles of seasonal movement caused a small but gradual ratcheting upward of pile bending moments. The largest bending moments measured over six years of monitoring were those resulting from the initial inward shrinkage of embankment, which reached about 25\% of the design capacity of the piles. At the end of the monitoring period, the measured bending moments resulting from shallower downslope ground movements were about $20 \%$ of the pile design capacity.
\end{abstract}

\section{Introduction}

Many clay railway embankments in the UK are over 100 years old, and pre-date the development of soil mechanics theory. The typical method of construction was to transport material, often clay excavated from areas of cut, along the embankment as it was built and tip it from the end. This created embankments of loose, poorly compacted clay fill, often standing at slopes exceeding their long-term stable angle (Skempton, 1996). Consequently, significant numbers of slopes failed either during or shortly after construction (Squire, 1880), as soil suctions within the clay clods were dissipated by rainfall infiltration. Embankments often settled considerably after construction, and additional material (often firebox ash) was added to the crest to maintain track level. Failures often left planes of weakness in the embankment 
structures; historic attempts at remediation, in the form of small rubble toe walls, or trench drains, are frequently apparent.

Many old embankments now suffer from a range of problems. During the steam era in the UK (up until the mid-1960s), lineside vegetation was managed to reduce fire risk. However, this practice declined when electric or diesel trains were introduced and many embankments became heavily vegetated. The removal of water by trees during a dry summer causes large shrinkage displacements that can disturb the level and/or line of the track (Andrei, 2000; O’Brien, 2007; Briggs et al., 2013b; Smethurst et al., 2015), requiring the imposition of speed limits or ongoing re-levelling works. Outright collapse can be triggered by periods of wet weather (Birch \& Dewar, 2002; Briggs et al., 2013a), and seasonal cycles of pore water pressure and movement may result in the development of progressive slope failure (Kovacevic et al., 2001; Nyambayo et al., 2004; Take \& Bolton, 2011). On the other hand, mature trees can generate soil suctions that persist through all but the wettest winters, lending crucial stability to the embankment slopes (O’Brien, 2007; Loveridge et al., 2010).

Discrete piles have been used both to stabilise existing earthwork slips and to prevent future failure of slopes having only a marginal factor of safety on strength (e.g. Carder \& Barker, 2005a, 2005b; Smethurst \& Powrie, 2007; O’Kelly et al., 2008). In embankment stabilisation applications, piles may be installed either at the midslope, where any potential slip is at its deepest, or at the crest to provide direct support to the railway running along the top (O’Brien, 2007). Compared with more conventional structures such as retaining walls, there are relatively few field data on how discrete piles bend and displace under the loads imposed by the slope. Further data on the long-term performance of these structures are therefore needed to aid effective design.

Discrete piles are often adopted as a stabilisation method where there is insufficient additional land to allow the construction of large toe berms or complete regrading of the slope. This same constraint means there is limited space to mobilise a piling rig onto the slope, and the process of constructing a piling platform requires much of the vegetation to be removed (e.g. Smethurst \& Powrie, 2007; O’Kelly et al., 2008). However, where mature vegetation is left in place to aid stability and provide a visual and acoustic screen, significant seasonal shrink and swell displacements are likely to continue. 
This paper presents field data from a study of a large, pile stabilised embankment at Mill Hill, north London, in which mature vegetation was left on the structure during and after pile stabilisation works. The paper reviews the effectiveness of the scheme over several years of monitoring, and makes observations about movements of stabilising piles that may result from shrink/swelling displacements within an earthwork.

\section{Background}

The instrumented piles form part of a scheme to stabilise a $12 \mathrm{~m}$ high glacial till (Lowestoft Formation) embankment, near Mill Hill in north London (Fig. 1; OS Grid Reference TQ245912). The embankment is between the London Underground stations at Mill Hill East and Finchley Central, and was constructed c1866 as part of the Edgware, Highgate and London Railway. The embankment increases in height in an easterly direction, reaching about $13 \mathrm{~m}$ before the railway passes onto a viaduct spanning Dollis Brook. The embankment was built for double track, but today carries only a single line.

The Lowestoft Formation embankment fill is a sandy silty clay with occasional fine to medium gravel, including fine gravel of chalk, and is of low to intermediate plasticity. It was likely obtained from an area of cut for the railway adjacent to Finchley Central station, where in situ deposits of the till are present. The embankment overlies in situ weathered London Clay. A layer of ash is present at the top of the embankment, below the track ballast. The embankment is covered with mature trees, predominantly oak and horse chestnut (Fig. 2).

The clay embankment has slope angles in the range $17-21^{\circ}$ (Fig. 3), including in places a steep (up to $30^{\circ}$ ) crest of granular ash and ballast. Inspections of the embankment condition in 1998 noted lateral and rotational movements of trees, lineside services and boundary fence posts. A ground investigation was carried out in 1999 comprising a mix of cable-percussion and window sample holes, and shallow trial pits at the toe of the embankment. Index, consolidated undrained triaxial and shear box tests were carried out on specimens of embankment fill material and the intact in situ London Clay. Table 1 gives plasticity, density and strength properties of the embankment materials. Trial pits revealed some evidence of relict shear surfaces within the toe 
of the earthwork, although these appeared to be discontinuous. A zone at the toe of the structure was therefore assumed to have a lower, pre-sheared, strength (Table 1).

Inclinometer tubes installed in 1999 at several locations along the crest of the embankment indicated downslope movements taking place, normally to about 3-4 m depth, also evident in the visible downslope displacement of a number of sections of the lineside cable runs. Toe bulging was also apparent along parts of the structure. An inclinometer tube at the crest close to the instrumented section (Fig. 3), read regularly over 32 months starting in summer 2001, showed downslope movement of about $10 \mathrm{~mm}$ at the top of the tube and substantial buckling of the tube to about $10 \mathrm{~m}$ depth, consistent with vertical ground settlements.

Analysis with pore water pressure conditions based on the London Underground Limited (LUL) standard (London Underground Ltd, 2000; see later) and piezometer measurements gave inadequate strength factors of safety against deep seated instability for parts of the embankment, and it was decided to stabilise the north side of the embankment by means of a row of midslope piles and a toe berm (Fig. 2b; Fig. 3). The berm was constructed in October 2004 of Type 1 fill material along the $140 \mathrm{~m}$ section of embankment over which piles were to be installed, to a height of about one-third that of the slope (Fig. 3). Only the trees directly in the path of the berm were removed as it was built. The berm provided access for the piling rig, with the stabilising piles constructed through the back edge of the platform (Fig. 3b) during December 2004 and January 2005. Towards the eastern end of the embankment, where instrumentation was installed, the discrete piles are $11.0 \mathrm{~m}$ long and $0.45 \mathrm{~m}$ in diameter, spaced at $0.70 \mathrm{~m}$ centres (1.56 diameters apart).

Crest stabilisation works were also carried out along short sections where the line side cables were being undermined by crest instability, and a transition structure was built to stiffen the embankment immediately adjacent to the viaduct (Fig. 3a).

\section{Instrumented embankment section}

A cross-section through the scheme was instrumented, as shown in plan in Figs. 3(a) and 4. The section comprises two piles instrumented with 10 no. pairs of vibrating wire strain gauges to determine bending strain and an inclinometer tube to measure pile displacement, and two 
further piles containing just an inclinometer tube (although one of these was subsequently damaged, and cannot now be read). More information on the pile instrumentation, including the make and model / type and arrangement of strain gauges, is given in Table 2. Inclinometer tubes were also installed in front of and just behind the pile row, to measure ground displacements (Table 3; Fig. 4). Vibrating-wire piezometers were installed, both close to the piles and slightly further up the embankment slope. The instrumented piles are labelled A-D and the slope inclinometer tubes, including that previously installed at the crest of the embankment, a-d (Fig. 4).

All of the inclinometer tubes and piezometers in the slope were installed prior to pile construction, and were grouted into boreholes using cement-bentonite grout. The piezometers were fully grouted (without sand packing at their tips) to enable measurement of pore water suctions. All of the instruments had flushing tubes running from the tip to the ground surface: these allow water to be circulated through the device to remove any build-up of air, following procedures detailed by Ridley et al. (2003) and Tarantino et al. (2008). TDR ThetaProbes were installed at 0.5, 1.0 and $1.5 \mathrm{~m}$ depth to measure water content changes near the surface of the embankment. The types, depths, measurement ranges and installation methods for the piezometers and water content probes are given in Table 4.

A weather station was installed at the site to measure rainfall and the parameters required to calculate potential evapotranspiration (temperature, relative humidity, wind speed and solar energy).

\section{Pile Design}

Limit equilibrium slope stability analyses were carried out to determine the critical slip surface and strength factor of safety in the absence of piles for a number of sections through the embankment. All slope stability analyses were carried out in two dimensions, using the Bishop method of analysis. Pore water pressures were adapted from Condition D in the LUL Standard (London Underground Ltd, 2000; hydrostatic beneath a zero pressure line $1.0 \mathrm{~m}$ below the ash/clay interface) on the basis of piezometer measurements taken over the period March 2001 to March 2003, to $70 \%$ of hydrostatic below a zero pressure line at a depth of $1.0 \mathrm{~m}$ below the clay surface. The piezometer measurement period included the end of the extreme wet winter 
of 2000/01 (Briggs et al, 2013a), during which piezometer measurements remained below hydrostatic, probably due to the significant summer desiccation by the mature trees growing on the slopes. Had the trees been removed, it would have been necessary to have used a more onerous pore pressure condition, potentially resulting in a more substantial pile scheme. For the instrumented section of slope, the stability analysis gave a strength factor of safety of just above 1.0, which was consistent with the signs of deformation in the embankment described earlier.

The initial slope stability model was changed to include the berm. Further analyses were then carried out to determine the minimum depth of the piles, such that any slip surfaces passing beneath the pile row had a factor of safety on soil strength of at least 1.15 against rotational slip (a value justified by the use of pre-sheared strength parameters within the toe zone of the slope, and based on guidance in the LUL Standard).

To model the action of the piles, a horizontal point force was applied at the intersection between the critical slip surface from the initial unreinforced analysis and the pile row, and progressively increased to achieve a factor of safety of 1.15 on the soil strength needed for slope stability. For the instrumented section of the slope, the critical unreinforced slip surface intersected the piles at a depth of $7.36 \mathrm{~m}$ below the ground surface and a stabilising point force of $76 \mathrm{kN} / \mathrm{m}$ was required to raise its factor of safety on strength from just above unity to 1.15.

Limit equilibrium calculations were then carried out to determine the pile length below the slip surface required for horizontal and moment stability of the pile row under the action of this force. All external forces acting on the pile row above the critical slip surface were represented by the point force determined from the slope stability analysis; below the slip surface, conventional active and passive pressures were assumed to act over the whole length of the installation (i.e. on both the piles and the gaps). These resistances were compared with those based on three-dimensional movement of soil around the piles (e.g. $\mathrm{K}_{\mathrm{p}}{ }^{2}$ from Fleming et al, 2009) acting on the pile width only. The small pile spacing adopted meant that the conventional active and passive distributions on the pile row considered as a continuous wall were more critical (i.e., gave a smaller net resistance) in this case. The calculation adopted a simplification in which the earth pressures acting below the point of pile rotation in the soil (fixed earth conditions) were ignored and the resulting length of pile below the assumed sliding surface increased by a factor of 1.2 (which is essentially the approach traditionally adopted for unpropped embedded retaining walls as described by Powrie, 2014). 
The limit equilibrium calculations followed Eurocode 7 (BS EN 1997-1, 2004; NA to BS EN 1997-1, 2007) Design Approach 1, for which three calculations were carried out: ULS Combination 1, ULS Combination 2, and an SLS calculation, using the partial factors on external load and soil strength given in Table 5. The bending moment distributions obtained from all three calculations are shown in Fig. 5, calculated per pile for comparison with the measured bending moment distributions (which are also plotted in Fig. 5 and will be discussed later). All three bending moment distributions were calculated by converting the point load from the sliding soil into an equivalent triangular pressure distribution increasing linearly from zero at ground level to a maximum at the depth of the assumed slip surface. Combination 2 gave the greatest pile length of $10.6 \mathrm{~m}$, and Combination 1 the greatest bending moment of 246 kNm per m length along the pile row.

The final pile design specified $11 \mathrm{~m}$ long, $450 \mathrm{~mm}$ diameter piles of bending capacity $184 \mathrm{kNm}$ per pile, spaced at $0.7 \mathrm{~m}$ centre-to-centre (Table 6). In this case, the diameter of the piles was limited by the size of the equipment that could be used on the embankment: retained trees overhung the piling platform and prevented use of a taller rig.

Additional slope stability analyses were carried out to ensure that the sections of slope above and below the pile row both had strength factors of safety greater than 1.15 against rotational failure.

\section{Pile and soil displacements}

Datum readings for the inclinometer tubes installed in the piles were taken on 19 December 2004, shortly after pile installation. The datum for the tubes in the slope adjacent to the pile row (tubes b-d) was taken as 07 January 2005, just after the initial readings from these tubes (Table 3). This was to remove displacements caused by pile construction, during which a movement of about 3 to $4 \mathrm{~mm}$ towards the pile row occurred as a result of stress relief in the clay (the pile bores were unsupported during construction). Further sets of inclinometer readings were taken at intervals over a period of 6 years following pile installation. The inclinometer data were analysed assuming that the pile toes had not displaced laterally. This is justified for Piles A and B by the fact that the slope of the measured displacement over the lowest few metres of each 
pile is zero. However, this is not the case for Pile $\mathrm{C}$, where the small measured rotation at the base (of about $1 \mathrm{~mm}$ over $3 \mathrm{~m}$ depth) is consistent with rotation about a point a short distance above the toe of the pile. Therefore the assumption that the pile toe does not displace laterally will introduce some error, but this is small relative to the total pile displacement. The inclinometer tubes installed just in front of and behind the pile row extended $4 \mathrm{~m}$ deeper than the piles and showed very little $(\sim 0.5 \mathrm{~mm})$ displacement adjacent to the pile toe, confirming that there was no significant lateral translation of the pile structure. The inclinometer probe used read to a resolution of $0.1 \mathrm{~mm}$ of lateral displacement for every $0.5 \mathrm{~m}$ depth, with a repeatability of measurement better than $+/-1.0 \mathrm{~mm}$ over the full depth of the tube.

Displacement data from the inclinometer tubes in Piles A, B and C are shown in Fig. 6, for a series of dates after pile construction.

Pile B (Fig. 6b) shows small downslope displacements of 1-2 mm through to October 2006. Movements then increased more rapidly to a pile head displacement of about $6 \mathrm{~mm}$ during the winter and spring of 2006/07. Since then, displacements have increased only slightly up to the summer of 2010 (pile head displacement about $7.5 \mathrm{~mm}$ downslope). The lowest 4-5 $\mathrm{m}$ of the pile has remained substantially vertical, with the maximum curvature occurring between about $3 \mathrm{~m}$ and $5 \mathrm{~m}$ depth. As discussed later, this behaviour is consistent with the downslope movement of a shallow ( 1.5 m) depth of soil being resisted by the pile, which is effectively embedded into the more stable underlying material.

The more recent data for Piles A and C (Fig. 6a and 6c) show a similar pattern of bending. However, the piles initially rotated or bent backwards into the slope, before downslope movements during the winter of 2006/07 (as seen in Pile B) started to reverse this trend. This backward rotation/bending is most pronounced in pile $\mathrm{C}$, and is attributed to the inward shrinkage of the embankment as the mature vegetation dried the clay fill. The summers of 2005 and 2006 and the intervening winter period were all relatively dry (Fig. 7). Bulk inward shrinkage of an embankment during drying has been observed elsewhere, including in model tests (Hudacsek et al., 2009; Take \& Bolton, 2011) and in the field (Bicocchi, 2011; Smethurst et al., 2015). The backward movement associated with the shrinkage of the embankment through to late summer 2006 caused the lower part of Pile C to rotate, and Piles A and B to bend upslope over the depth range 5-8 $\mathrm{m}$. 
Displacement data from inclinometer tubes b-d installed in front of and behind the pile row are shown in Fig. 8. Displacements recorded behind the pile row (Fig. 8a) remained generally small. Some upslope movement occurred during late summer 2006, consistent with the backward movement of piles A and C (Fig. 9a). Soil displacements in front of the piles have been larger, with downslope movements of up to $12 \mathrm{~mm}$ extending over the top 2-3 $\mathrm{m}$ depth of soil. Over the reasonably wet winter of 2006/07 (Fig. 7), soil displacements increased by about $3 \mathrm{~mm}$, although there is little recorded change after summer 2007. These downslope displacements are indicative of fairly shallow movements in the clay fill just beneath the berm, and are clearly the cause of the downslope bending in the piles (Fig. 9b). However, seasonal pile displacements are still visible in the small reversals in movement over later summer periods (e.g. the piles move upslope between May 2009 and September 2009; Fig. 6).

\section{Bending moments}

\section{Calculation of bending moments from strain gauge readings}

In general, it is desirable to take strain datums a short time after pile installation, to eliminate the effect on the strain gauge readings of concrete shrinkage during curing, most of which occurs in the first few days after casting (Bakoss et al., 1977; Murdock et al., 1991; Bicocchi, 2011). In the current application this is reasonable as long as it can be ascertained that the piles have not started to carry any load from the slope in the intervening period. For the piles at Mill Hill, the inclinometer readings confirm that no significant movement occurred during the first month, and the bending strain datum for each pile was taken at 15 days after pile installation (Table 2).

Crack propagation is often evidenced by rapid jumps in the strain gauge readings (e.g. Bicocchi, 2011). There is no sign of this at Mill Hill. The piles are therefore assumed to have remained uncracked, and bending moments were calculated from a modified form of the stress-strain relationship given in Eurocode 2 (BS EN 1992-1-1, 2004). The procedure is explained in the Appendix.

Measured bending moments 
The bending moments measured by pairs of strain gauges within each pile are plotted against time in Fig. 10. In both Piles B and C, bending moments steadily increased from installation to reach a maximum in mid-summer 2005. These peak bending moments were associated with the upslope movement of the upper parts of the piles as the embankment shrank inward due to tree water uptake. Negative moments (associated with compression on the upslope side) were generated over the bottom half of each pile as the piles bent upslope, and positive moments (tension on the upslope side) over the top half (particularly in Pile C) where the piles bent back in the downslope direction. This is consistent with the deflected shapes of the piles measured by the inclinometers (Fig. 6). Profiles of bending moment with depth are shown in Fig. 11.

During late 2006 and early 2007, wetter weather caused a clear net movement of the piles downslope, driven partly by the shallow displacements measured at the inclinometer tubes c and $\mathrm{d}$, installed into the soil downslope of the pile row (Fig. 8b and c). The bending moments over the lower half of Pile B moved from negative to slightly positive; while in Pile $\mathrm{C}$ the large positive moments at 1.70 and $2.55 \mathrm{~m}$ depth fell substantially (Figs. 10 and 11). From mid-2007 onwards, bending moments remained largely unchanged, except for a clear seasonal fluctuation in the readings. The bending moments increased fairly rapidly in early winter, only to reduce gradually again over much of the mid- and late summer. These cycles of bending moment are consistent with the seasonal forward and backward movements of the piles measured by the inclinometers. Moments over the upper parts of the piles cycle back to the starting point, but there is a gentle ratcheting upward of moments over the lower parts of the piles (Fig. 10).

While there are seasonal variations in pile bending after mid-2007, the general bending behaviour of the piles after this point (small bending moments at the base, and larger downslope bending moments over the top part of the pile) is consistent with the predominantly downslope shallow movements measured at inclinometer tubes c and $\mathrm{d}$. This pile bending behaviour is very similar to that measured at Grange Hill by Bicocchi (2011), where the piles were also resisting fairly shallow (circa 2-3 m depth) downslope ground movements. The last measured bending moments are less than $20 \%$ of the design bending capacity of the piles (Fig. 5).

\section{Seasonal variations in soil water content and pore water pressure, and their influence on slope movements}


Profiles of pore water pressure measured by piezometers installed adjacent to the piles are shown in Fig. 12 for a number of dates over the monitoring period. The initial (March and November 2005) profiles show negative pore water pressures to about $4.0 \mathrm{~m}$ depth, below which pore pressures were positive but sub hydrostatic. The positive pore pressures measured through a large part of the embankment and in the top of the London Clay foundation are consistent with the founding material being low permeability London Clay (Briggs et al, 2013a).

Pore water pressures gradually increased over the monitoring period with some seasonal fluctuations, reaching a peak around February 2010 (Fig. 13a). Pore water pressures above 4.0 m depth varied from low suctions $(<10 \mathrm{kPa})$ during winter, to moderate suctions $(\sim 40 \mathrm{kPa})$ in the summer. The shallow piezometers installed above the berm, which were about $4.5 \mathrm{~m}$ horizontally from a mature horse chestnut tree, routinely measured the maximum suction the device could read during the summer $(\sim 70 \mathrm{kPa})$ and fell close to zero during the winter (not shown). This strong seasonal variation is also seen in the measured water contents in Fig. 13(b), which show substantial summer drying throughout the measured profile (to $1.5 \mathrm{~m}$ depth). The extent and depth of drying is consistent with observations from other tree-covered embankments (Briggs 2010; Smethurst et al., 2015), and is much greater than measured for rough grass vegetation (e.g. Greenwood et al., 2001; Smethurst et al., 2012).

The mature trees growing on the earthwork are clearly able to cause substantial summer soil drying to at least $4.0 \mathrm{~m}$ depth. This helps to maintain a profile of pore water pressures close to zero, even during winter, within the uppermost $4 \mathrm{~m}$ or so of the mid-slope; as well as generally less-than-hydrostatic pore water pressures below this. Apart from the winter of 2010, the measured pore water pressures remained below the design pore water pressure profile (of $70 \%$ hydrostatic, as given in Fig. 12) throughout the monitoring period.

Field measurements from a tipped London Clay embankment (Smethurst et al., 2015), and a London Clay highway cutting (Ridley, 2012; 2017) show horizontal upslope movements close to the ground surface of 5 to $20 \mathrm{~mm}$ during summer soil drying, and subsequent downslope movements of similar magnitude during wetting. The upslope shrinkage movements measured during summer 2006 at Mill Hill of 3-4 mm are smaller than for the London Clay earthworks, which is consistent with the relatively lower plasticity of the Lowestoft Formation fill material. In principle, the ground movements can be linked quantitatively with the shrinkage of the soil 
under related changes in pore water pressure/ water content. For example, tests by Monroy (2005) on compacted London Clay in a suction-controlled oedometer showed shrinkage and swelling volumetric strains of $\sim 1 \%$ for cycles of applied suction from 5 to $95 \mathrm{kPa}$.

For Mill Hill, a quantitative calculation was not carried out, because: (i) there was insufficient information about soil suction changes above $4.0 \mathrm{~m}$ depth, where some measured suctions exceeded the maximum that the piezometers were able to read; (ii) there were no laboratory shrinkage data for the Lowestoft clay fill; and (iii) it was not clear how (probably 1D) laboratory shrinkage behaviour relates to (likely 3D) movements at slope scale, owing to uncertainty about soil cracking and the exact direction of inward shrinkage of the embankment. However, it is almost certain that the observed substantial soil drying at Mill Hill is the cause of the measured upslope movements of the piles into the embankment, and the maximum pile bending moment of $50 \mathrm{kNm}$ obtained during the monitoring period (Fig. 10b).

Later movements and bending of the piles are governed predominantly by the gradual shallow movement of the slope surface and berm in front of the pile row. Shallow movements of this type are commonly observed in clay earthwork slopes (e.g. Parsons \& Perry, 1985; Greenwood, 1998), and occur as a result of the seasonal cycles of wetting and drying within the surface zone. Even if the higher winter/spring surface pore water pressures do not cause the surface of the slope to become unstable, seasonal shrinkage and swelling of the clay may cause gradual net downslope movements. Ridley (2017) used data from adjacent extensometer and inclinometer installations within a London Clay cutting to show that inward drying/shrinkage displacements occurred perpendicular to the slope surface, while the outward horizontal component of movement on swelling was much larger, so that over a drying and wetting cycle a net downslope displacement occurred. Hudacsek et al., (2009) and Take \& Bolton (2011) show similar net downslope displacements under cycles of drying and wetting in centrifuge model tests on clay slopes. Furthermore, high plasticity clay soils will crack on drying (e.g. Anderson et al, 1982); a mechanism may be postulated in which desiccation cracks both open and close mainly in the downslope direction under the influence of gravity, also causing a net downslope displacement over a wetting and drying cycle (Fig. 14).

There is no indication of deeper-seated movements, either interacting with or developing below the pile row, as seen in 2D finite element analyses of a pile wall stabilised cut slope in clay 
presented by Summersgill et al., (2018); at Mill Hill the slope inclinometer tubes extend below the toe of the piles, and do not show any displacements forming below the structure.

\section{Pile-soil pressures and relative pile-soil displacements}

The bending moments estimated from measured strains in Piles B and C on 24 August 2006 are shown as data points in Fig. 15(a). A series of six (no.) fourth-order polynomial splines (Georgiadis et al., 1992; Smethurst \& Powrie, 2007) were fitted through each of these data sets, and differentiated once and twice to obtain respectively the shear force and net soil line load (in $\mathrm{kN} / \mathrm{m}$ ) acting on the piles (Fig. 15c and d). The spline curves were also integrated twice to obtain pile displacements, which are compared in Fig. 15(b) with the measured inclinometer profiles. The Pile C displacement spline was rotated by -16/EI radian at the base (i.e., the first constant of integration was non-zero) to match the measured inclinometer profile. This reinforces the earlier observation that the Pile $\mathrm{C}$ inclinometer profile at this stage indicates a slight backward rotation of the whole pile.

A uniform flexural rigidity (EI) of $81710 \mathrm{kNm}^{2}$, corresponding to an uncracked pile section, was used to calculate the displacement spline. The splines give a reasonably close match to both the strain-derived bending moment and inclinometer displacement data, indicating that the assumption that the piles have not cracked is appropriate. This is because cracking tends to affect the strain gauges and inclinometer data differently, resulting in a difference in the flexural rigidities needed to match the bending moments obtained from the strains to those from the displacements (see further comment in the Appendix).

The net line load splines in Fig. 15(d) show net pressures acting downslope over the top $1 \mathrm{~m}$ to $1.5 \mathrm{~m}$ depth of each pile, and upslope below this to about $4 \mathrm{~m}$ depth. At depths greater than about $4 \mathrm{~m}$, the net pressures are downslope but switch back to upslope over the bottom 2-3 $\mathrm{m}$ of the piles. To explain this pattern of net pressure distribution, it must be recalled that until late summer 2006, the movement of the embankment was predominantly inward (i.e., upslope) as a result of soil shrinkage. This drove pile movement, with rotation of the pile resisted by the pressures lower down (below $4 \mathrm{~m}$ depth) and those close to the ground surface (top 1m depth), where the pile head displacement is likely greater than the soil (shrinkage) movements. Upslope pressures over the lowest part of the pile provide a degree of fixity at the base: for Pile C, which 
appears to be less well fixed at depth, these upslope pressures extend over a greater length of the pile (3 m compared with $2 \mathrm{~m}$ ) than for Pile B.

The relative pile/soil movements, based on the measured pile movements and the expected lateral soil shrinkage are shown schematically in Fig. 16(a). These are consistent with the net pile pressures (line loads) shown in Fig. 15(d).

Spline fits to the bending moments measured in Piles B and C on 8 July 2010, by which time shallow downslope soil movements had become dominant, are shown in Fig. 17(a). The measured inclinometer displacements are compared with the bending moment splines integrated twice in Fig. 17(b). The shear forces and line loads calculated by differentiating the bending moment splines once and twice respectively are shown in Figs. 17(c) and (d). The net line load distributions shown in Fig. 17(d) are similar to those in Fig. 15(d) over the uppermost $5 \mathrm{~m}$. Below this, generally small pressures act in the downslope direction and the upslope pressures near the toe are lost, consistent with the very small negative bending moments measured in the lower parts of the piles. Pile displacements are predominantly downslope, driven mainly by the shallow downslope pressures acting on the uppermost $2 \mathrm{~m}$ of the piles. The downslope force on the head of the pile, as determined from the line load spline, was 20 $\mathrm{kN} / \mathrm{m}$ (per m length of slope) for Pile B, and $14 \mathrm{kN} / \mathrm{m}$ for Pile C.

Relative pile/soil movements, based on the pile and soil movements measured by the inclinometers, are indicated schematically in Fig. 16(b). These are again consistent with the net pile pressures (line loads) in Fig. 17(d).

\section{Discussion}

The piles at Mill Hill have been subjected to different mechanisms of ground movement at different times. The embankment shrunk bodily inward (upslope) during an initially quite dry period, as the earthwork became desiccated by the mature trees growing on it. This caused the piles to bend backwards into the slope, with the peak measured bending moment of $50 \mathrm{kNm}$ ( $\sim 25 \%$ of the pile design capacity) associated with this deep (up to $4 \mathrm{~m}$ ) inward shrinkage of the embankment. Over a longer and generally wetter period, starting with the autumn and winter of 2006-07, the piles became loaded in the downslope direction as a result of shallow ( $2 \mathrm{~m}$ 
depth) seasonal ratcheting shrink/swell movements in the earthwork. Small but gradual increases in bending moment (of 3-5 kNm per cycle) were observed each winter on the lower part of the piles. While bending moments might increase further if this behaviour were to continue, the pressure on the upper parts of the piles will be limited by that needed to stabilise a minor shallow slip, or ultimately the development of passive failure conditions in the soil upslope of the piles.

The pile head displacements (7 mm total) and their rate of increase ( $1 \mathrm{~mm} / \mathrm{year})$ at Mill Hill are small compared with other instrumented sites at Hildenborough (Smethurst \& Powrie, 2007) and Grange Hill (Bicocchi, 2011), where pile head displacements of up to $50 \mathrm{~mm}$ and rates of increase of $4 \mathrm{~mm} / \mathrm{yr}$ were measured. This is probably because ground movements at Mill Hill have been dominated by shrinkage and swelling, rather than slope instability.

The trees at Mill Hill have caused changes in soil water content extending to several metres depth, significantly greater than might be expected for grass/small shrub cover. This has caused the shrinkage and swelling of the ground responsible for the measured pile behaviour. The mature vegetation has also helped to maintain the generally low pore water pressures measured in the embankment during the winter, which - apart from a period in early 2010 - have remained below the design profile. Leaving the mature vegetation on the embankment enabled the use of a lower than hydrostatic design pore water pressure profile, which likely resulted in a smaller stabilisation scheme than would have been required had the trees been removed.

\section{Conclusions}

1. Pore water pressures and ground movements within a pile-stabilised railway embankment at Mill Hill, London, have been shown to be influenced by the large trees covering much of the earthwork. The changes in soil water content in the tree root zone, and the associated lateral soil displacements, are larger and deeper in extent than those measured at sites with shallow (grass and shrub) vegetation cover. The design of the stabilisation scheme assumed that the trees would maintain lower than hydrostatic pore water pressures in the earthwork during the winter; measurements show maximum pore water pressures consistent with the design pore water pressure profile. 
2. A dry period during 2005 and early 2006 resulted in reasonably deep ( $\sim \mathrm{m})$ inward shrinkage of the earthwork. This dominated the early behaviour of the stabilising piles, causing them to move inwards (upslope). This resulted in an unusual pile bending mechanism, in which the piles bent upslope (causing compression on the upslope side) over their lower halves, and back downslope (causing tension on the upslope side) at the top of each pile.

3. A wetter period starting in the autumn and winter of $2006 / 2007$ brought a steady seasonal increase in shallower (2 $\mathrm{m}$ depth) downslope displacements measured by inclinometer tubes installed in front of the pile row. This generally reduced upslope bending at the base of each pile, and increased downslope bending moments and displacements over the upper half.

4. After the winter of 2006/2007, bending moments in the lower halves of the piles ratcheted upward by 4-5 $\mathrm{kNm}$ each winter, as a result of seasonal shrink/swell movements in the earthwork. There is potential for these bending moments to accumulate, if this behaviour continues into the future. Generally the bending moments relative to the ultimate pile capacity, and the pile head displacements, are smaller than seen on other sites over a similar period of measurement. This is because movements at Mill Hill have been dominated by the shrinkage and swelling of the earthwork, rather than a more obvious slope instability.

5. Pile bending moments were calculated from both strain gauge measurements and by curve fitting to pile displacements, using the same flexural rigidity for uncracked concrete. Close correlation was obtained, suggesting that for the small bending moments that currently act, the piles have remained uncracked.

\section{Appendix: Calculation of bending moment from strain gauges assuming no cracking}

The following approach was used to convert the longitudinal strains $\varepsilon_{1}$ and $\varepsilon_{2}$ measured by each pair of strain gauges into bending moment $\mathrm{M}$ :

(a) The strain gauge readings $\varepsilon_{1}$ and $\varepsilon_{2}$ give the strain profile through the pile section based on the section remaining plane. The pile was assumed to remain uncracked, and a bending strain profile was created by shifting the measured strain profile laterally so that the neutral axis passed through the centre of the pile section (Fig. 18a). 
(b) The plan area of the pile was divided into a series of small strips running parallel to the neutral axis. The proportion of each strip made up of steel and concrete was determined from the rebar layout (Fig. 18b). The bending strain profile in (a) was then used to find the strain acting in each strip.

(c) The stress acting in each strip was determined from the strain in (b) and the non-linear stress-strain relationships for steel and concrete from Eurocode 2 (BS EN 1992, 2004), with a long term, fully hardened value of $\mathrm{E}$ for concrete of $35 \times 10^{6} \mathrm{kN} / \mathrm{m}^{2}$ based on an estimate of the 90-day strength of the concrete (informed by concrete cube tests on similar C35 concretes). This was applied to all of the data, i.e. E was not reduced over the first 90 days while the concrete gained strength. The tensile strength of the concrete is assumed to be unlimited, as cracking was not detected. The composite uncracked flexural rigidity, EI, calculated for the piles is given in Table 5 .

(d) The bending moment was then determined as the sum of the stresses in each strip multiplied by the lever arm of the strip about the neutral axis.

The bending moments determined from pile inclinometer displacements were calculated using the average composite uncracked flexural rigidity (EI) of $81710 \mathrm{kNm}^{2}$, as given in Table 6 .

The close correlation obtained between the bending moments calculated from the strain gauge readings and those from spline fitting to the inclinometer results indicates that the assumption that the piles have not cracked is appropriate. If the pile cracks, strain gauges in the tension side of the pile and between adjacent cracks will likely see a reduction in strain; thus the bending moment calculated in part accounts for pile cracking. To get bending moments determined from inclinometer profiles to match, the flexural rigidity (EI value) used in spine fitting must be reduced to a value below that in the bending strain calculation, to similarly incorporate the effects of cracking on the bending moments obtained (see Smethurst and Powrie, 2007; Bicocchi, 2011).

\section{Acknowledgements}

The research described in this paper was funded by the UK Engineering and Physical Sciences Research Council (EPSRC) under grant numbers GR/S30696/01, EP/F063482/1 and 
EP/H044949/1. Design of the scheme was carried out by Mott MacDonald, and site works by Fondedile Foundations. The rainfall data set for Golders Hill was obtained from the UK Metrological Office via the UK Natural Environment Research Council (NERC) Centre for Environmental Data Analysis (CEDA). Many thanks go to Harvey Skinner who built the datalogger systems and Alex Dykes who helped with monitoring of the instrumentation. James Scott at Mott MacDonald assisted with information on the scheme design, and initial review of the monitoring data. Arlo Dew of Tube Lines provided invaluable assistance with the installation of instrumentation on site. All data supporting this study are openly available from the University of Southampton repository at \{doi: number to be added\}.

\section{References}

Anderson, M.G., Hubbard, M.G. and Kneale P.E. (1982). The influence of shrinkage cracks on pore-water pressures within a clay embankment. Quarterly Journal of Engineering Geology \& Hydrogeology 15(1): 9-14.

Andrei, A. (2000). Embankment stabilisation works between Rayners Lane and South Harrow Underground stations. Ground Engineering, 33, No. 1, 24-26.

Birch, G. P. and Dewar, A. L. (2002), Earthwork failures in response to extreme weather, In: Forde, M.C. (ed.) Proceedings of the International Conference Railway Engineering 2002, London, UK. Engineering Technics Press, Edinburgh.

Bakoss, S. L., Burfitt, A. J. \& Cridland, L. (1977). Measurement of strains in concrete members with vibrating wire strain gauges. Australian Road Research 7, No. 3, 21-26.

Bicocchi, N. (2011). Structural and geotechnical interpretation of strain gauge data from laterally loaded reinforced concrete piles. PhD Thesis, University of Southampton.

Briggs, K. M. (2010). Charing embankment: climate change impacts on embankment hydrology. Ground Engineering. June. 28-31.

Briggs, K. M., Smethurst, J. A., Powrie, W., \& O’Brien, T. (2013a). Wet winter pore pressures in railway embankments. Proceedings of the ICE: Geotechnical Engineering. 166, (GE5), 451-465. (doi:10.1680/geng.11.00106).

Briggs, K.M., Smethurst, J.A., Powrie, W., O'Brien, A.S. \& Butcher, D. (2013b) Managing the extent of tree removal from railway earthwork slopes. Ecological Engineering, 61, (Part C), 690-696. (doi:10.1016/j.ecoleng.2012.12.076).

BS EN 1992-1-1 (2004). Eurocode 2: Design of Concrete Structures, BS EN 1992-1-1. British Standards Institution: London. 
BS EN 1997-1 (2004). Eurocode 7: Geotechnical Design, Part 1: General Rules. BS EN 1997-1. British Standards Institution: London.

Carder, D. R. \& Barker, K. J. (2005). The performance of a single row of spaced bored piles to stabilise a Gault Clay slope on the M25, TRL Report TRL627, Crowthorne: TRL Limited.

Carder, D. R. \& Barker, K. J. (2005). The performance of a single row of spaced bored piles to stabilise a London Clay slope on the A12, TRL Report TRL642, Crowthorne: TRL Limited.

Fleming, W. G. K., Weltman, A. J., Randolph M. F. \& Elson, W. K. (2009). Piling Engineering. London: Taylor \& Francis.

Georgiadis, M., Anagnostopoulos, C. \& Saflekou, S. (1992). Centrifugal testing of laterally loaded piles in sand. Canadian Geotechnical Journal. 29, No. 2, 208-216.

Greenwood, D.A. (1998). Speculations on methods of stabilizing slopes. Proceedings of the ICE: Ground Improvement, 2, (3), 103-123.

Greenwood, J. R., Vickers, A. W., Morgan, R. P. C., Coppin, N. J. \& Norris, J. E. (2001). Bioengineering: the Longham Wood Cutting field trial, CIRIA Project Report 81. London: Construction Industry Research and Information Association.

Hudacsek, P., Bransby, M. F., Hallett, P. D. \& Bengough, G. (2009). Centrifuge modelling of climatic effects on clay embankments. Proceedings of the ICE: Engineering Sustainability. 162 ES2, 91-100.

Kovacevic, N., Potts, D. M., \& Vaughan, P. R. (2001). Progressive failure in clay embankments due to seasonal climate change. Proceedings of the $15^{\text {th }}$ ICSMGE, Istanbul, Turkey. Vol. 3, 2127-2130.

London Underground Ltd (2000). Earth Structures: Assessment. London Underground Ltd, October 2000, E3321 A4.

Loveridge, F. A., Spink, T. W., O'Brien, A. S., Briggs, K. M. and Butcher, D. (2010). The impact of climate and climate change on UK infrastructure slopes, Quarterly Journal of Engineering Geology and Hydrogeology 43, 461 - 472.

Monroy, R. (2005). The influence of load and suction changes on the volumetric behaviour of compacted London Clay. PhD Thesis, Imperial College London.

Murdock, L. J., Brook, K. M. \& Dewar, J. D. (1991). Concrete materials and practice. London: Edward Arnold.

NA to BS EN 1997-1 (2007). UK National Annex to Eurocode 7: Geotechnical Design, Part 1: General Rules. NA to BS EN 1997-1. British Standards Institution: London.

Nyambayo, V. P., Potts, D. M. \& Addenbrooke, T. I. (2004). The influence of permeability on the stability of embankments experiencing seasonal cyclic pore water pressure changes. 
Advances in Geotechnical Engineering: Proceedings of the Skempton Conference, Imperial College, London, Vol. 2, 898-910.

O’Brien, A. S. (2007). Rehabilitation of urban railway embankments - investigation, analysis, and stabilisation. Proceedings of the $14^{\text {th }}$ European Conference on Soil Mechanics and Geotechnical Engineering, Madrid, 1, 125-143.

O’Kelly, B. C., Ward, P. N., \& Raybould, M. J. (2008). Stabilisation of a progressive railway embankment slip. Geomechanics and Geoengineering: An International Journal. 3, No. 4, 231-244.

Parsons, A. W. \& Perry, J. (1985). Slope stability problems in aging highway earthworks. Proceedings of the Symposium on Failures in Earthworks. ICE, London. 63-78.

Powrie, W. (2014). Soil mechanics: concepts and applications. Taylor and Francis: London.

Ridley, A. M., Dineen, K., Burland, J. B. \& Vaughan P. R. (2003). Soil matrix suction: some examples of its measurement and application in geotechnical engineering. Géotechnique 53, (2), 241-253 (doi:10.1680/geot.2003.53.2.241)

Ridley, A. M. (2012). Relationships between climate, vegetation, pore water pressures and the serviceability of clay slopes. Rivista Italiana Geotecnica 3, 15-28.

Ridley, A. M. (2017). Monitoring the performance of clay slopes. Institution of Civil Engineers John Mitchel Lecture. A recording of the lecture is available at:

www.ice.org.uk/eventarchive/john-mitchell-lecture-2017 (last accessed on 18 March 2018).

Skempton, A. W. (1996). Embankments and cuttings on the early railway. Construction History, 11, 33-49.

Smethurst, J.A., Briggs, K.M., Powrie, W., Ridley, A. and Butcher, D. J. E. (2015)

Mechanical and hydrological impacts of tree removal on a clay fill railway embankment.

Géotechnique, 65, (11), 869-882 (doi:10.1680/geot.14.p.010).

Smethurst, J. A., Clarke, D. \& Powrie, W. (2012). Factors controlling the seasonal variation in soil water content and pore water pressures within a lightly vegetated clay slope. Géotechnique, 62, (5), 429-446. (doi:10.1680/geot.10.p.097).

Smethurst, J. A. \& Powrie, W. (2007). Monitoring and analysis of the bending behaviour of discrete piles used to stabilise a railway embankment. Géotechnique 57 (8), 663-677.

(doi:10.1680/geot.2007.57.8.663).

Squire, J. B. (1880). Earthworks slips in the cuttings and embankments of various railways, with their causes and modes of treatment. Minutes of the Proceedings of the Institution of Civil Engineers, 62, Part 4, 272-287.

Summersgill, F. C., Kontoe, S. \& Potts, D. M. (2018). Stabilisation of excavated slopes in strain-softening materials with piles. Géotechnique 68 (7), 626-639.

(doi:10.1680/jgeot.17.P.096). 
Take, W. A. \& Bolton, M. D. (2011). Seasonal ratcheting and softening in clay slopes, leading to first-time failure. Géotechnique, 61, (9), 757-769. (doi:10.1680/geot.9.P.125)

Tarantino, A., Ridley A. M. \& Toll, D. G. (2008). Field measurement of suction, water content, and water permeability. Geotechnical and Geological Engineering, 26, 751-782. (doi: 10.1007/s10706-008-9205-4)

Wan, M. S. P. \& Standing J. R. (2013). Field measurement by fully grouted vibrating wire piezometers. Proceedings of the ICE: Geotechnical Engineering. 167, (GE6), 547-564. 
Tables

\begin{tabular}{|c|c|c|c|c|c|c|}
\hline \multicolumn{2}{|c|}{ Material } & $\begin{array}{l}\text { Unit weight: } \\
\gamma\left(\mathrm{kN} / \mathrm{m}^{3}\right)\end{array}$ & $\begin{array}{c}\text { Effective } \\
\text { cohesion: c' } \\
(\mathrm{kPa})\end{array}$ & $\begin{array}{c}\text { Friction } \\
\text { angle: } \phi^{\prime} \\
\text { (degrees) }\end{array}$ & $\begin{array}{l}\text { Liquid limit: } \\
\text { LL }_{\mathrm{L}} \%\end{array}$ & $\begin{array}{l}\text { Plasticity } \\
\text { index: } \mathrm{I}_{\mathrm{p}} \%\end{array}$ \\
\hline \multicolumn{2}{|c|}{ Ash } & 11 & 0 & 40 & - & - \\
\hline \multirow{2}{*}{$\begin{array}{c}\text { Lowestoft } \\
\text { Formation } \\
\text { glacial till } \\
\text { embankment } \\
\text { fill }\end{array}$} & $\begin{array}{c}\text { Full strength } \\
\text { parameters }\end{array}$ & 19 & 1 & 25 & \multirow[t]{2}{*}{38.0} & \multirow[t]{2}{*}{24.3} \\
\hline & $\begin{array}{c}\text { Pre-sheared } \\
\text { parameters }\end{array}$ & 19 & 1 & 18 & & \\
\hline \multicolumn{2}{|c|}{$\begin{array}{l}\text { Weathered London Clay } \\
\text { Formation }\end{array}$} & 19 & 2 & 21 & 72.6 & 42.7 \\
\hline
\end{tabular}

\section{Table 1: Soil properties}

\begin{tabular}{|c|c|c|c|c|c|}
\hline $\begin{array}{l}\text { Instrumented } \\
\text { pile number } \\
\text { (pile number } \\
\text { in row) }\end{array}$ & $\begin{array}{c}\text { Pile } \\
\text { construction } \\
\text { date }\end{array}$ & Strain gauges & $\begin{array}{l}\text { Strain } \\
\text { gauge } \\
\text { datum } \\
\text { reading }\end{array}$ & Inclinometer tube & $\begin{array}{l}\text { Inclinometer } \\
\text { datum reading }\end{array}$ \\
\hline $\mathrm{A}(76)$ & $\begin{array}{c}15 \\
\text { December } \\
2004\end{array}$ & None & $\mathrm{n} / \mathrm{a}$ & \multirow{4}{*}{$\begin{array}{l}\text { Soil Instruments } 70 \\
\text { mm diameter easy- } \\
\text { connect plastic } \\
\text { inclinometer } \\
\text { casing: } 10.8 \mathrm{~m} \text { long }\end{array}$} & $\begin{array}{c}19 \text { December } \\
2004\end{array}$ \\
\hline B (80) & $\begin{array}{c}15 \\
\text { December } \\
2004\end{array}$ & \multirow{2}{*}{$\begin{array}{l}10 \text { pairs of Soil } \\
\text { Instruments } \\
\text { vibrating wire } \\
\text { concrete } \\
\text { embedment type } \\
\text { strain gauges, at } \\
\text { approximately } 1.0 \\
\text { m spacing down } \\
\text { the pile. }\end{array}$} & $\begin{array}{c}30 \\
\text { December } \\
2004\end{array}$ & & $\begin{array}{c}19 \text { December } \\
2004\end{array}$ \\
\hline C (83) & $\begin{array}{c}16 \\
\text { December } \\
2004\end{array}$ & & $\begin{array}{c}31 \\
\text { December } \\
2004\end{array}$ & & $\begin{array}{c}19 \text { December } \\
2004\end{array}$ \\
\hline $\mathrm{D}(85)$ & $\begin{array}{c}16 \\
\text { December } \\
2004\end{array}$ & None & $\mathrm{n} / \mathrm{a}$ & & $\begin{array}{c}19 \text { December } \\
2004\end{array}$ \\
\hline
\end{tabular}

Table 2: Instrumentation installed into piles

\begin{tabular}{|c|c|c|c|c|}
\hline $\begin{array}{c}\text { Slope inclinometer } \\
\text { tube }\end{array}$ & Installation date & Tube type & $\begin{array}{l}\text { Tube depth, from } \\
\text { ground surface: } \mathrm{m}\end{array}$ & Inclinometer datum \\
\hline $\mathrm{a}$ (crest) & 1999 & \multirow{4}{*}{$\begin{array}{c}70 \mathrm{~mm} \text { diameter } \\
\text { plastic } \\
\text { inclinometer } \\
\text { casing }\end{array}$} & 20 & 1999 \\
\hline $\begin{array}{c}\text { b (upslope of pile } \\
76)\end{array}$ & $\begin{array}{c}08 \text { November } \\
2004\end{array}$ & & 14 & 07 January 2005 \\
\hline $\begin{array}{l}\text { c (downslope of } \\
\text { pile 76) }\end{array}$ & $\begin{array}{c}09 \text { November } \\
2004\end{array}$ & & 14 & 07 January 2005 \\
\hline $\begin{array}{l}\mathrm{d} \text { (downslope of } \\
\text { pile } 85)\end{array}$ & $\begin{array}{l}16 \text { November } \\
2004\end{array}$ & & 14 & 07 January 2005 \\
\hline
\end{tabular}

Table 3: Slope inclinometer tube installation details 


\begin{tabular}{|c|c|c|c|c|c|}
\hline $\begin{array}{l}\text { Instrument } \\
\text { group }\end{array}$ & $\begin{array}{c}\text { Installation } \\
\text { date }\end{array}$ & $\begin{array}{l}\text { Instrument } \\
\text { type }\end{array}$ & $\begin{array}{l}\text { Instrument } \\
\text { depths: m }\end{array}$ & $\begin{array}{l}\text { Measurement } \\
\text { range }\end{array}$ & Installation method \\
\hline $\begin{array}{l}\text { Piezometers } \\
\text { downslope } \\
\text { of the pile } \\
\text { row }\end{array}$ & $\begin{array}{c}10-17 \\
\text { November } \\
2004\end{array}$ & \multirow[t]{2}{*}{$\begin{array}{c}\text { Soil } \\
\text { Instruments } \\
\text { vibrating } \\
\text { wire } \\
\text { flushable } \\
\text { piezometer }\end{array}$} & $\begin{array}{c}2.0,3.0,4.5, \\
6.0,7.2,9.0, \\
\text { m; installed } \\
\text { in three } \\
\text { boreholes }\end{array}$ & $\begin{array}{l}\text { Positive water } \\
\text { pressures to } 100 \\
\mathrm{kPa} \text {; negative } \\
\text { pressures } \\
\text { depend on depth } \\
\text { of installation, } \\
\text { with } 2.0 \mathrm{~m} \\
\text { device to about - } \\
70 \mathrm{kPa} \text {, and } 9.0 \\
\text { m device to just } \\
\text { below } 0 \mathrm{kPa} \text {. }\end{array}$ & \multirow{2}{*}{$\begin{array}{l}\text { The piezometers were } \\
\text { installed in } 100 \mathrm{~mm} \\
\text { diameter boreholes, } \\
\text { supported to the correct } \\
\text { depth using plastic } \\
\text { standpipe tubing. The } \\
\text { borehole was then fully } \\
\text { grouted using cement- } \\
\text { bentonite grout designed } \\
\text { to seal the piezometers (i.e. } \\
\text { have a low enough } \\
\text { permeability, see Tarantino } \\
\text { et al., 2008) and transmit } \\
\text { suction from the soil to the } \\
\text { ceramic of the piezometer. } \\
\text { This is an increasingly } \\
\text { common installation } \\
\text { approach for piezometers; } \\
\text { see Wan and Standing } \\
\text { (2013). }\end{array}$} \\
\hline $\begin{array}{l}\text { Piezometers } \\
\text { upslope of } \\
\text { pile row }\end{array}$ & $\begin{array}{l}08 \text { March } \\
2005\end{array}$ & & $\begin{array}{l}1.2 \text { and } 1.8 \\
\text { m; installed } \\
\text { in } \\
\text { individual } \\
\text { boreholes }\end{array}$ & $\begin{array}{l}\text { Positive water } \\
\text { pressures to } 100 \\
\text { kPa; negative } \\
\text { pressures to } \\
\text { about }-70 \mathrm{kPa} \text {. }\end{array}$ & \\
\hline $\begin{array}{c}\text { TDR } \\
\text { ThetaProbes } \\
\text { upslope of } \\
\text { pile row }\end{array}$ & $\begin{array}{c}05 \\
\text { November } \\
2004\end{array}$ & $\begin{array}{c}\text { Delta-T } \\
\text { Devices } \\
\text { ML2x } \\
\text { ThetaProbe }\end{array}$ & $\begin{array}{l}0.5,1.0 \text { and } \\
1.5 \mathrm{~m} ; \\
\text { installed in } \\
\text { individual } \\
\text { boreholes }\end{array}$ & $\begin{array}{c}\text { Measure } \\
\text { volumetric soil } \\
\text { water content } \\
\text { between } 0 \text { and } \\
0.5 \mathrm{~m}^{3} / \mathrm{m}^{3}\end{array}$ & $\begin{array}{l}\text { The pins of the ThetaProbe } \\
\text { were pushed into the soil } \\
\text { at the bottom of a vertical } \\
50 \text { mm diameter hand- } \\
\text { augured hole using } \\
\text { proprietary extension } \\
\text { tubes, and the borehole } \\
\text { then filled with cement- } \\
\text { bentonite grout. }\end{array}$ \\
\hline
\end{tabular}

Table 4: Piezometer and TDR ThetaProbe installation details and measurement range

\begin{tabular}{|c|c|c|c|}
\hline \multirow{3}{*}{$\begin{array}{l}\text { Combination of partial } \\
\text { factors }\end{array}$} & \multicolumn{3}{|c|}{ Partial factors } \\
\hline & \multirow[t]{2}{*}{ Applied load } & \multicolumn{2}{|c|}{$\begin{array}{ll}\text { Soil strength } \\
\end{array}$} \\
\hline & & $\begin{array}{l}\text { Effective friction angle, } \\
\text { tan } \phi\end{array}$ & Effective cohesion, c’ \\
\hline ULS Combination 1 & 1.35 & 1.0 & 1.0 \\
\hline ULS Combination 2 & 1.0 & 1.25 & 1.25 \\
\hline SLS & 1.0 & 1.0 & 1.0 \\
\hline
\end{tabular}

Table 5: Partial factors applied to pile length calculation

\begin{tabular}{|c|c|c|c|c|c|}
\hline $\begin{array}{c}\text { Instrumented } \\
\text { pile number } \\
\text { pile number } \\
\text { in row) }\end{array}$ & $\begin{array}{c}\text { Pile length } \\
\text { and } \\
\text { diameter }\end{array}$ & Concrete & Reinforcement bars & $\begin{array}{c}\text { Bending } \\
\text { capacity: kNm }\end{array}$ & $\begin{array}{c}\text { Uncracked flexural } \\
\text { rigidity: kNm }{ }^{2}\end{array}$ \\
\hline
\end{tabular}




\begin{tabular}{|c|c|c|c|c|c|}
\hline $\begin{array}{l}A(76) \\
B(80) \\
C(83) \\
D(85)\end{array}$ & $\begin{array}{l}\text { Length } \\
11.0 \mathrm{~m} \text {; } \\
\text { diameter } \\
450 \mathrm{~mm}\end{array}$ & $\begin{array}{c}35 \\
\mathrm{~N} / \mathrm{mm}^{2}\end{array}$ & $\begin{array}{l}\text { Main steel: } 8 \text { no. } \\
\text { T25 bars; Shear } \\
\text { reinforcement: T10 } \\
\text { at } 200 \mathrm{~mm} \text { spacing, } \\
\text { with } 75 \mathrm{~mm} \text { cover. }\end{array}$ & $\begin{array}{l}263 \mathrm{kNm} \text { per m } \\
\text { length of pile } \\
\text { row, or } 184 \mathrm{kNm} \\
\text { per pile. }\end{array}$ & $\begin{array}{l}81710 \mathrm{kNm}^{2} \text { : an } \\
\text { average value for all } \\
\text { tens pairs of strain } \\
\text { gauges determined } \\
\text { from the bending } \\
\text { moment calculation } \\
\text { described in the } \\
\text { Appendix. }\end{array}$ \\
\hline
\end{tabular}

Table 6: Instrumented pile geometry, bending capacity and flexural rigidity

\section{Figure Captions}

Fig. 1: Location Plan

Fig. 2: Photographs of the site showing (a) the top of the embankment (19 May 2009); and (b) the toe berm and instrumented section at the end of construction works (12 April 2005). Note the extensive mature vegetation retained on the slope post-construction.

Fig. 3: (a) plan, and (b) cross section through the stabilised embankment

Fig. 4: Layout of the instrumentation within the monitored section (cross section Fig. 3b).

Fig. 5: Bending moment profiles obtained from limiting equilibrium pile design, plotted with the pile bending moment measured using pairs of strain gauges and splines fitted to the measured moments. A technical problem meant that the strain gauges on Pile C below $8.0 \mathrm{~m}$ depth did not record after May 2010, and thus the plotted bending moment points for these gauges are for May 2010 rather than July 2010.

Fig. 6: Pile inclinometer displacements: (a) Pile A; (b) Pile B; and (c) Pile C. Downslope displacements are denoted positive.

Fig. 7: Rainfall recorded at the Mill Hill site from December 2004 to March 2007, and at Golders Hill, $4.5 \mathrm{~km}$ from the site, for the remainder of the periods shown: (a) annual and 6month totals 1990-2010; and (b) monthly totals 2004-2010.

Fig. 8: Slope inclinometer displacements: (a) tube b; (b) tube c; and (c) tube d. Downslope displacements are denoted positive.

Fig. 9: Comparison of displacements measured by Pile A, and slope inclinometer tubes b and c, immediately upslope and downslope of Pile A: (a) 24 August 2006 (20 months after installation of instruments); and (b) 08 July 2010 (66 months after installation).

Fig. 10: Bending moment plotted against time (a) Pile B; and (b) Pile C.

Fig. 11: Bending moment plotted against depth (a) Pile B; and (b) Pile C.

Fig. 12: Profiles of pore water pressure measured by piezometers installed from the front edge of the berm. 
Fig. 13: (a) pore water pressures plotted with time for select piezometers installed in the clay slope from the front edge of the berm structure; and (b) water content plotted with time measured using TDR ThetaProbes installed in the clay slope just upslope of the berm. The spikes in the readings in (a) indicate when the piezometers were flushed (i.e. had water circulated through them to remove any presence of air). It then takes a few days for the device to come back into equilibrium with the water pressures in the soil.

Fig. 14: Postulated mechanism of surface downslope movement in which deep desiccation cracks: (a) open during summer in the downslope direction, and (b) close during winter, also in the downslope direction. (Note that movements of the individual crack faces on opening and closing may not both be in the downward direction as idealised here, but the net movement after crack opening and closing would be downslope).

Fig. 15: Splines fitted to measured pile bending moments for Piles B and C for 24 August 2006: (a) splines fitted to the measured bending moment from the strain gauges; (b) displacement splines and measured inclinometer displacements; (c) shear force obtained by differentiating the splines in (a); and (d) net line load profile obtained by twice differentiating the splines in (a).

Fig. 16: Idealised pile-soil interaction mechanisms: (a) upslope displacements of piles due to embankment shrinkage within the tree rooting zone; and (b) downslope displacements of piles due to surface instability.

Fig. 17: Splines fitted to measured pile bending moments for Piles B and C for 10 July 2010: (a) splines fitted to the measured bending moment from the strain gauges (note bottom three gauge readings for Pile C are taken from when the gauges last functioned in early 2010); (b) displacement splines and measured inclinometer displacements; (c) shear force obtained by differentiating the splines in (a); and (d) net line load profile obtained by twice differentiating the splines in (a).

Fig. 18: (a) Distributions for bending and axial strain through a pile assuming an uncracked section; (b) concrete and steel sections used in the calculation of bending moment. 
12 June 2018

Behaviour of discrete piles used to stabilise a tree-covered railway embankment

Smethurst J A, Bicocchi N, Powrie W, O’Brien A S

\section{Figures}

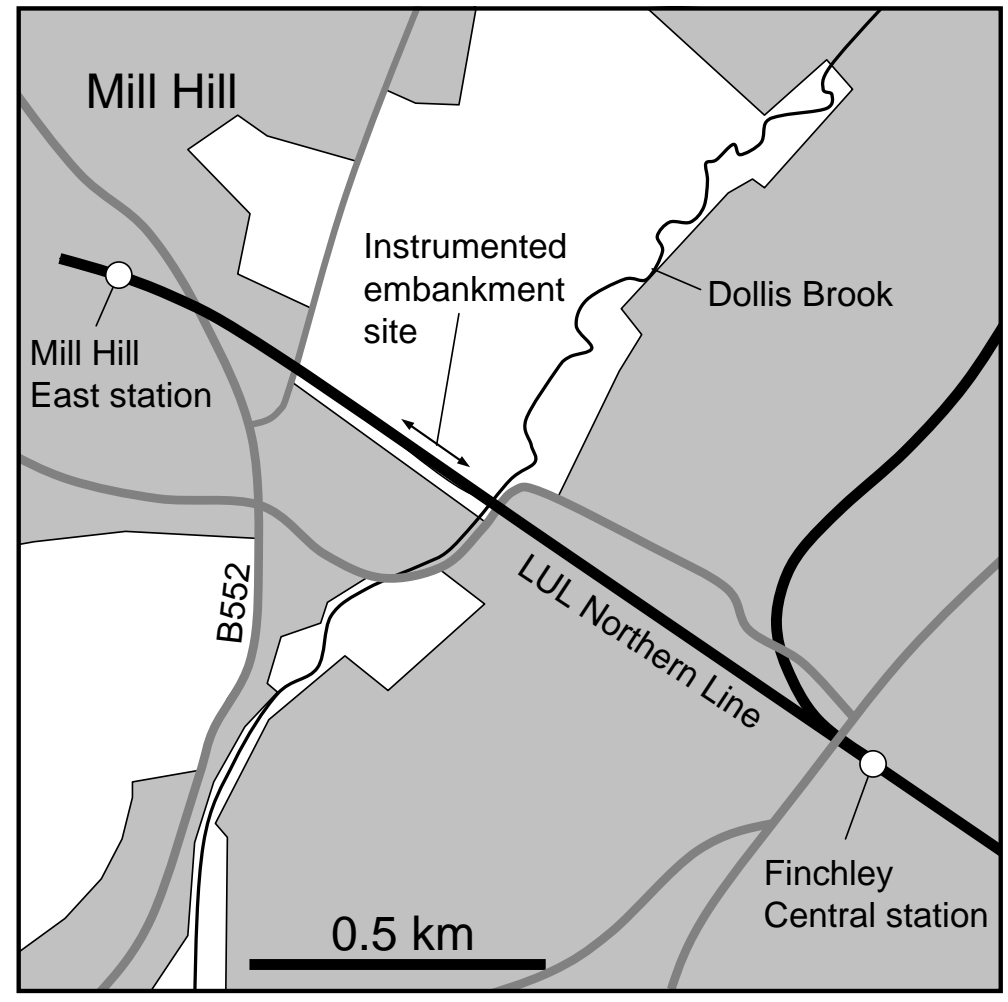

Fig. 1: Location Plan 


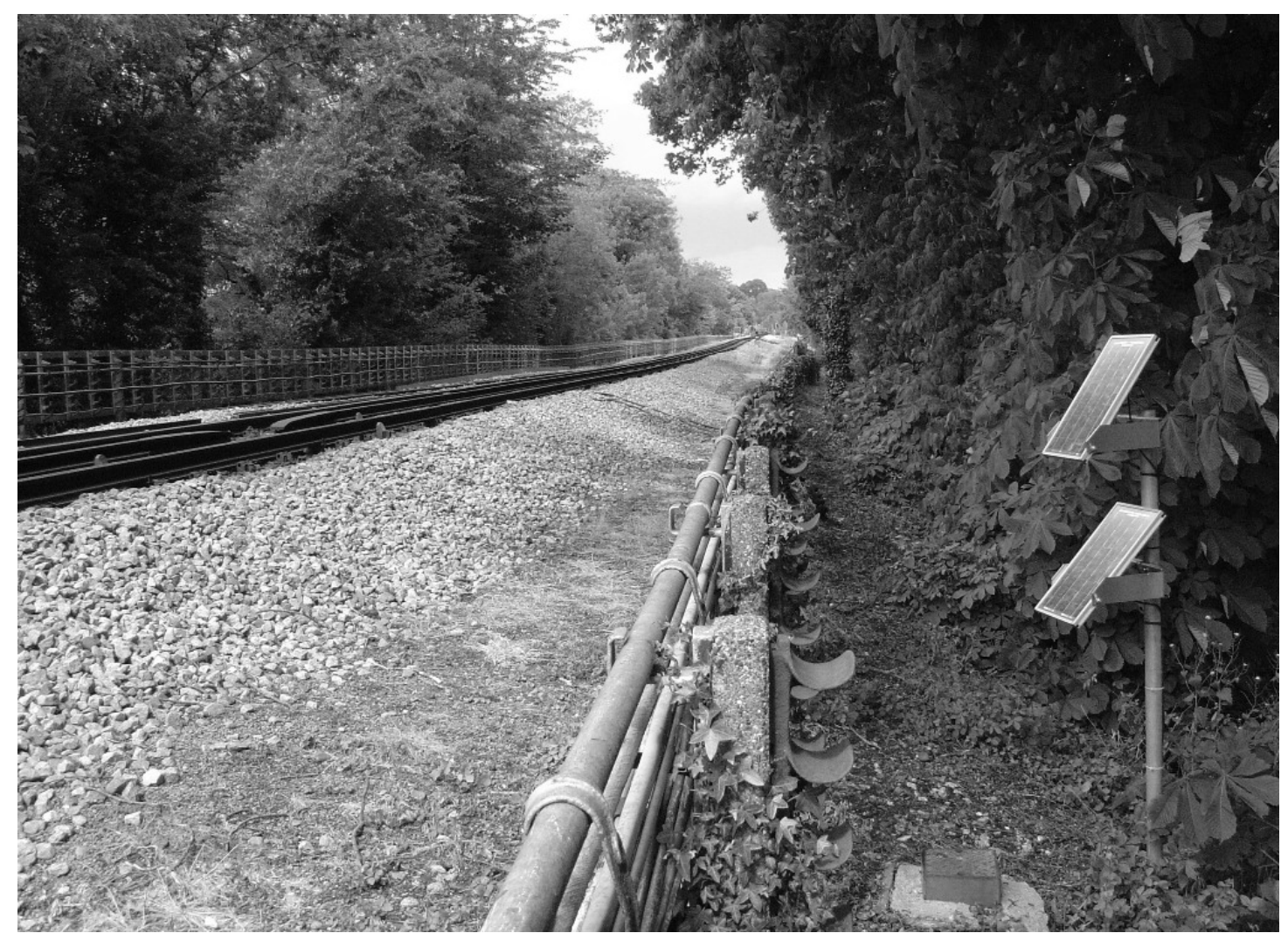

(a)

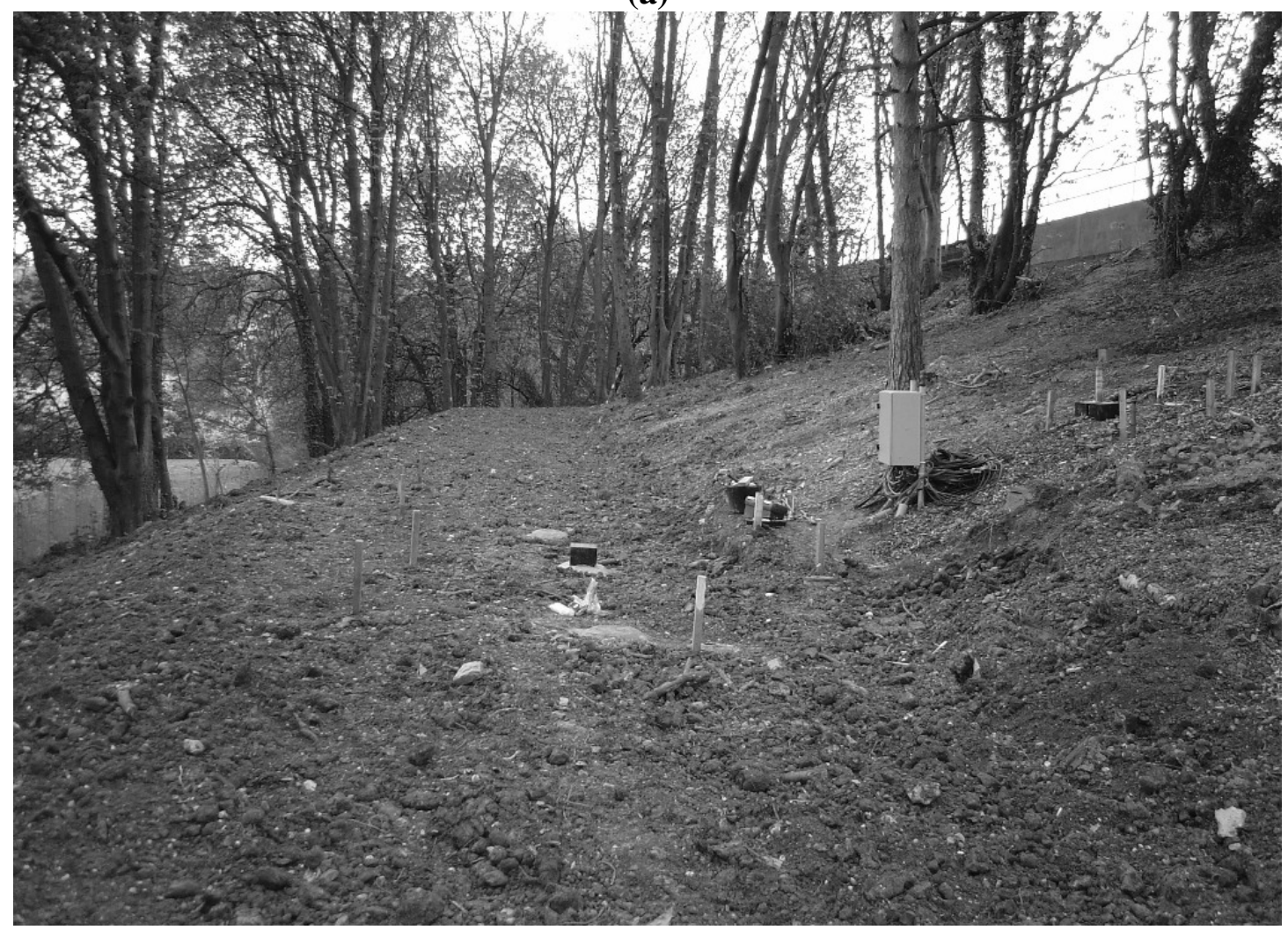

(b)

Fig. 2: Photographs of the site showing (a) the top of the embankment (19 May 2009); and (b) the toe berm and instrumented section at the end of construction works (12 April 2005). Note the extensive mature vegetation retained on the slope postconstruction. 


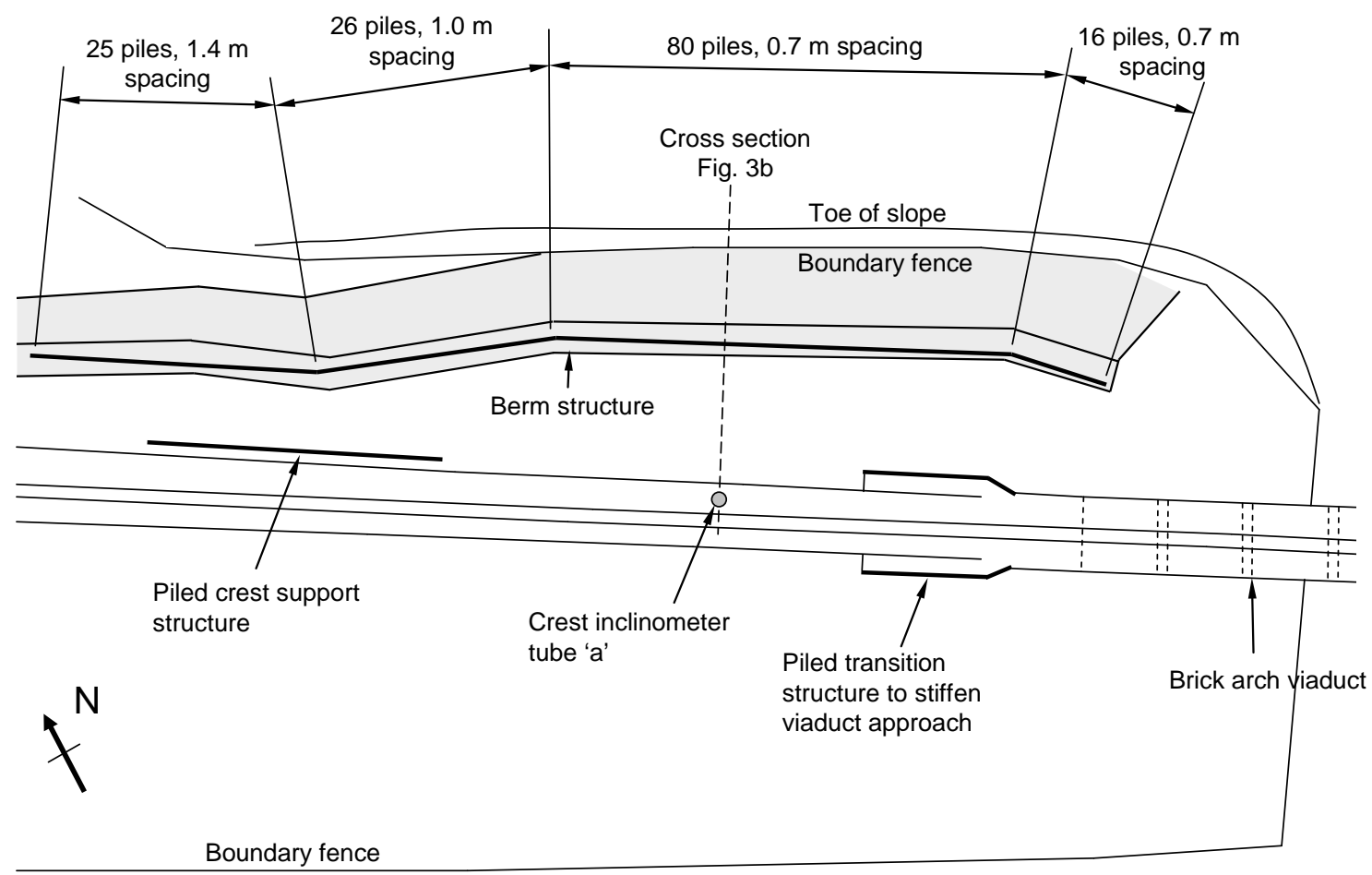

(a)

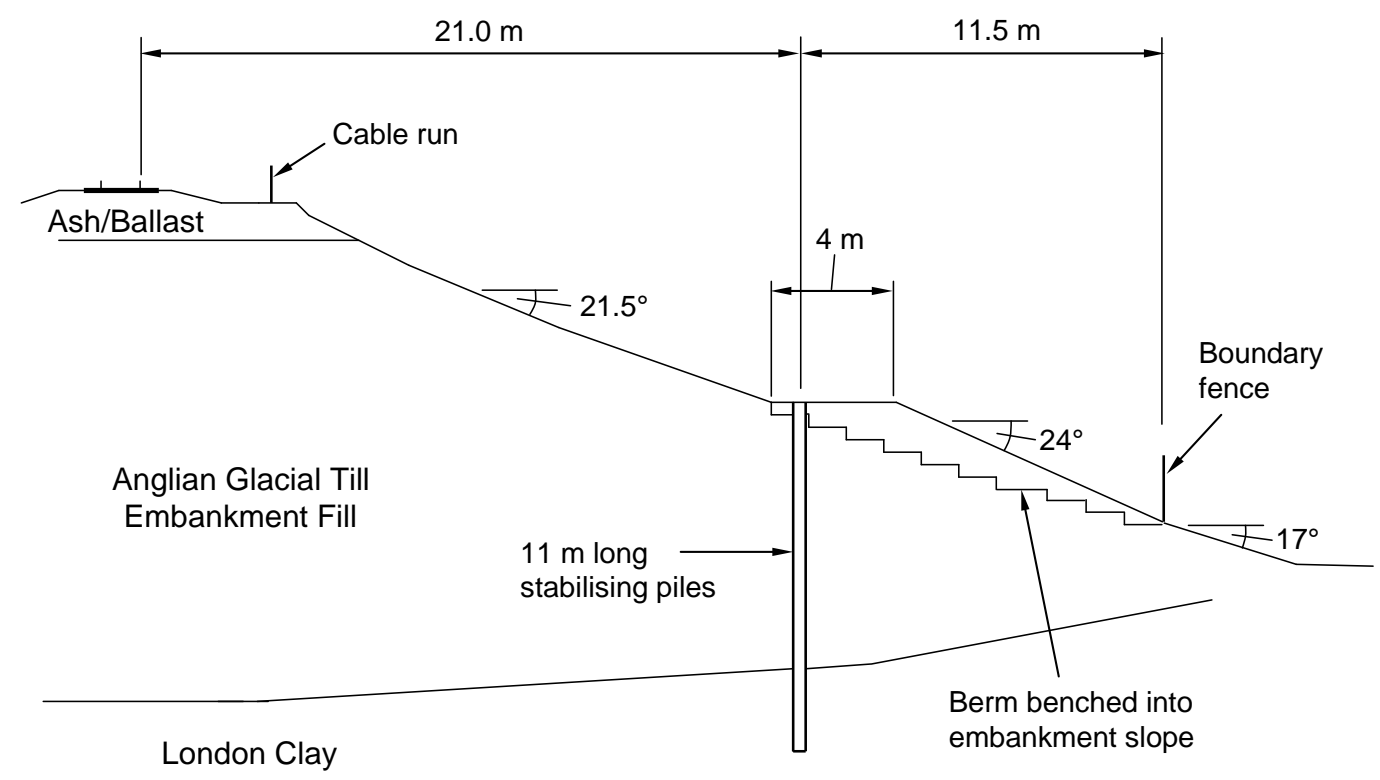

(b)

Fig. 3: (a) plan, and (b) cross section through the stabilised embankment 


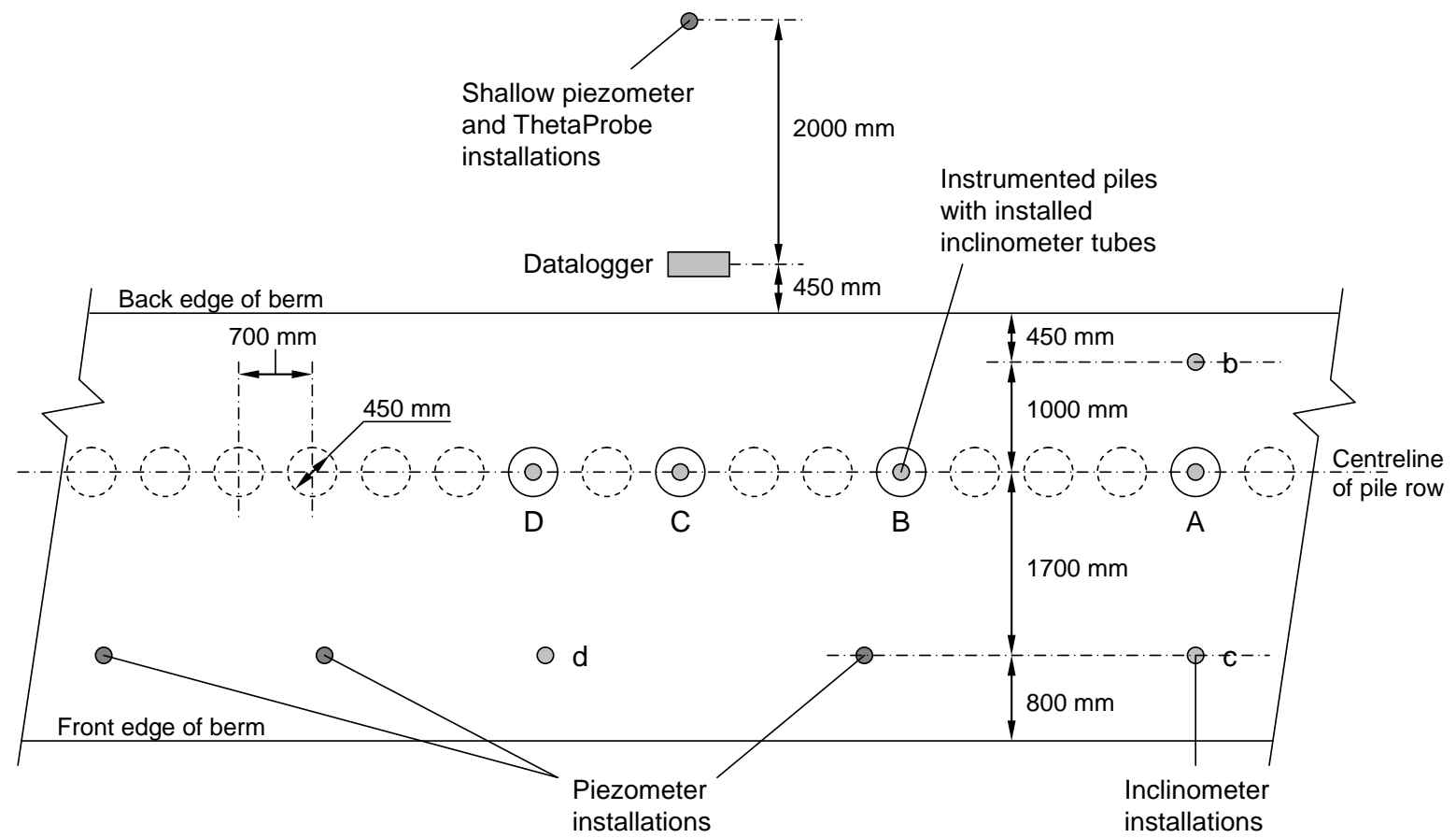

Fig. 4: Layout of the instrumentation within the monitored section (cross section Fig. 3b). 


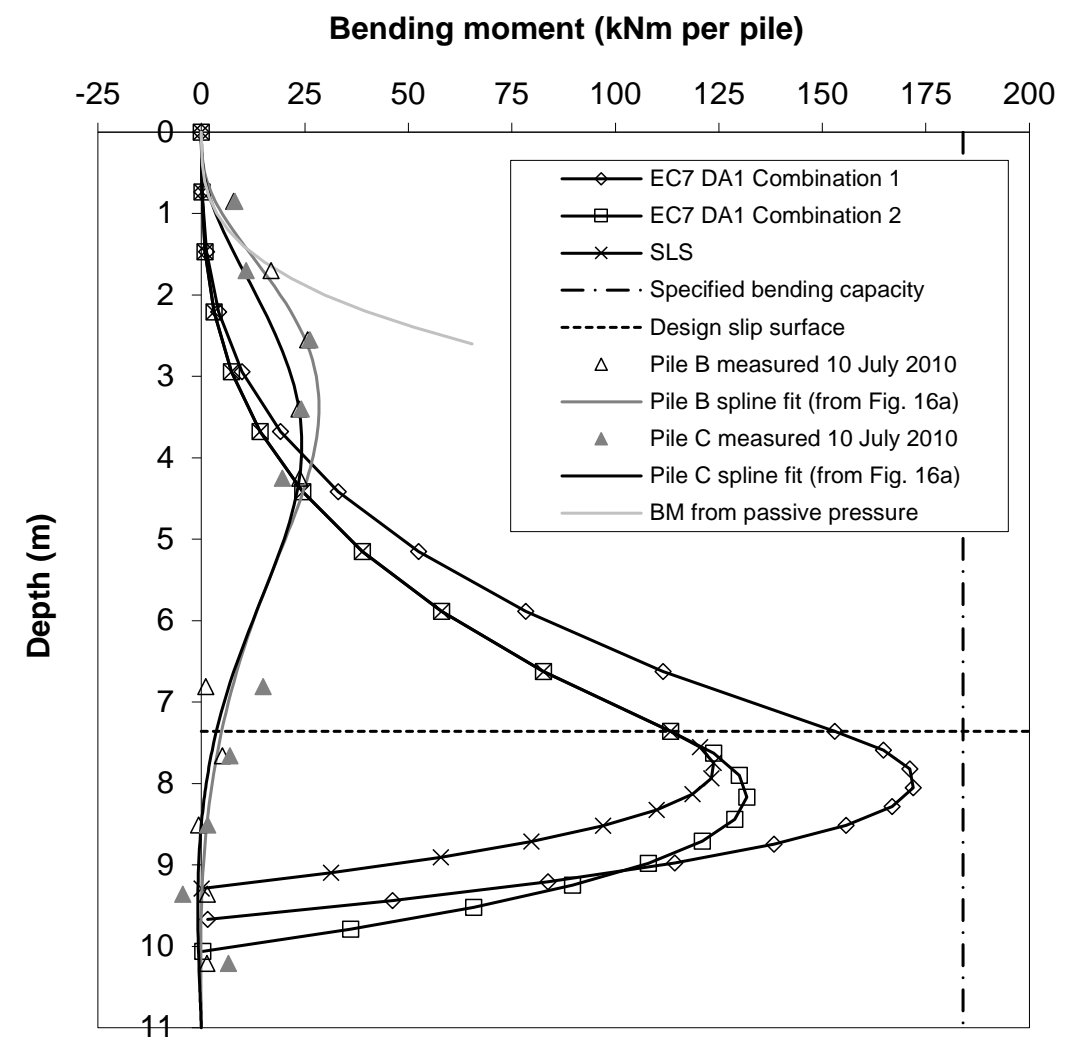

Fig. 5: Bending moment profiles obtained from limiting equilibrium pile design, plotted with the pile bending moment measured using pairs of strain gauges and splines fitted to the measured moments. A technical problem meant that the strain gauges on Pile $\mathrm{C}$ below $8.0 \mathrm{~m}$ depth did not record after May 2010, and thus the plotted bending moment points for these gauges are for May 2010 rather than July 2010. 


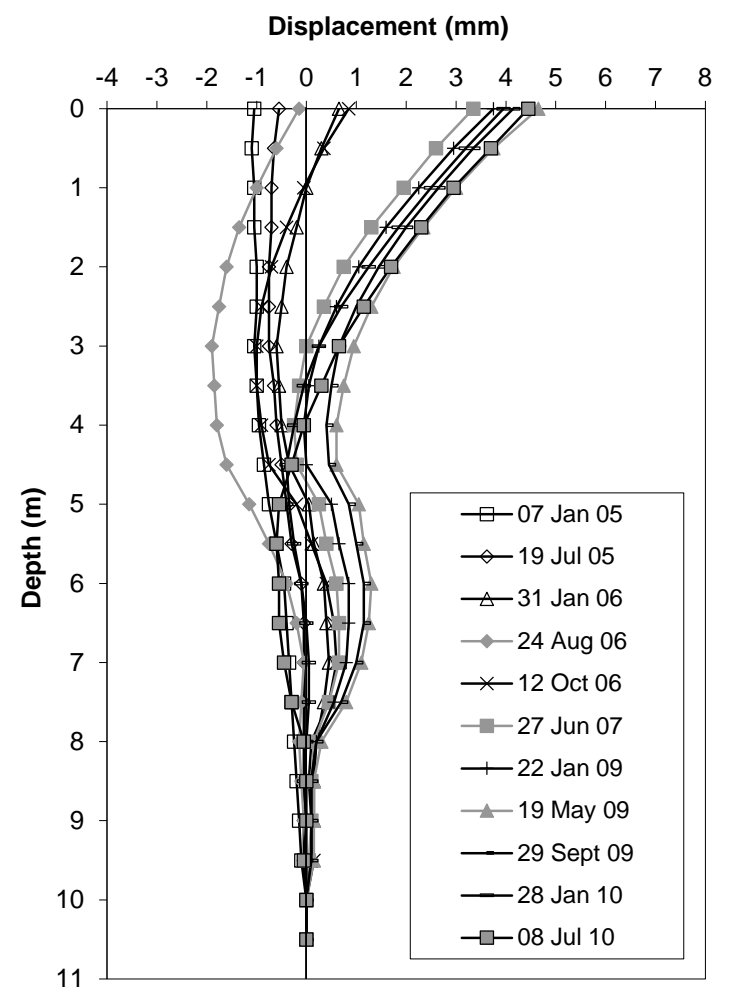

(a)

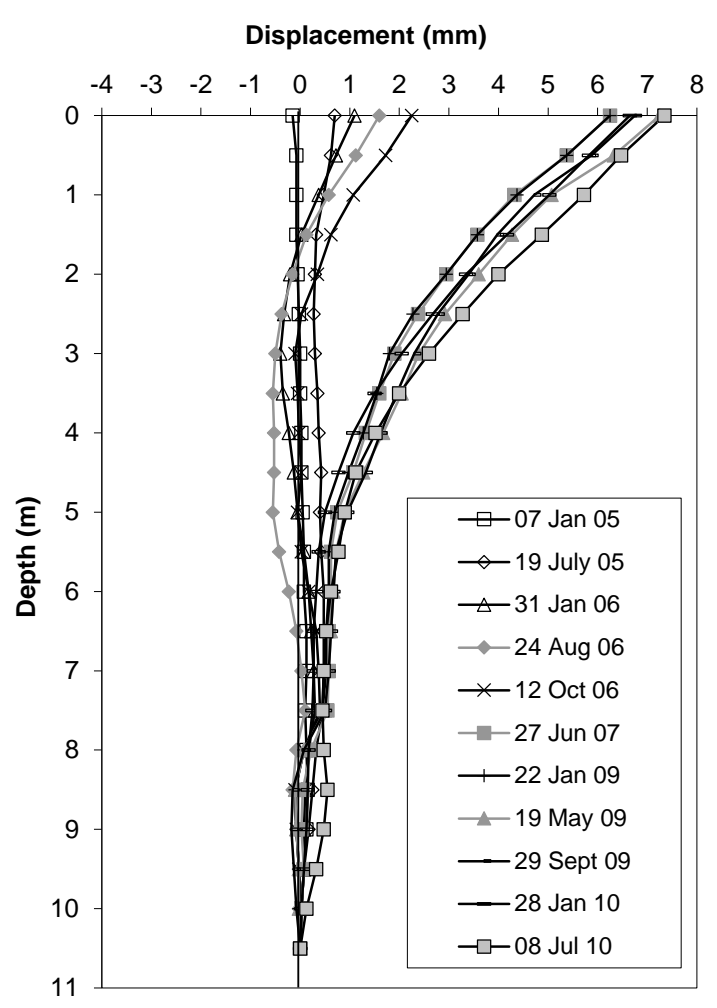

(b)

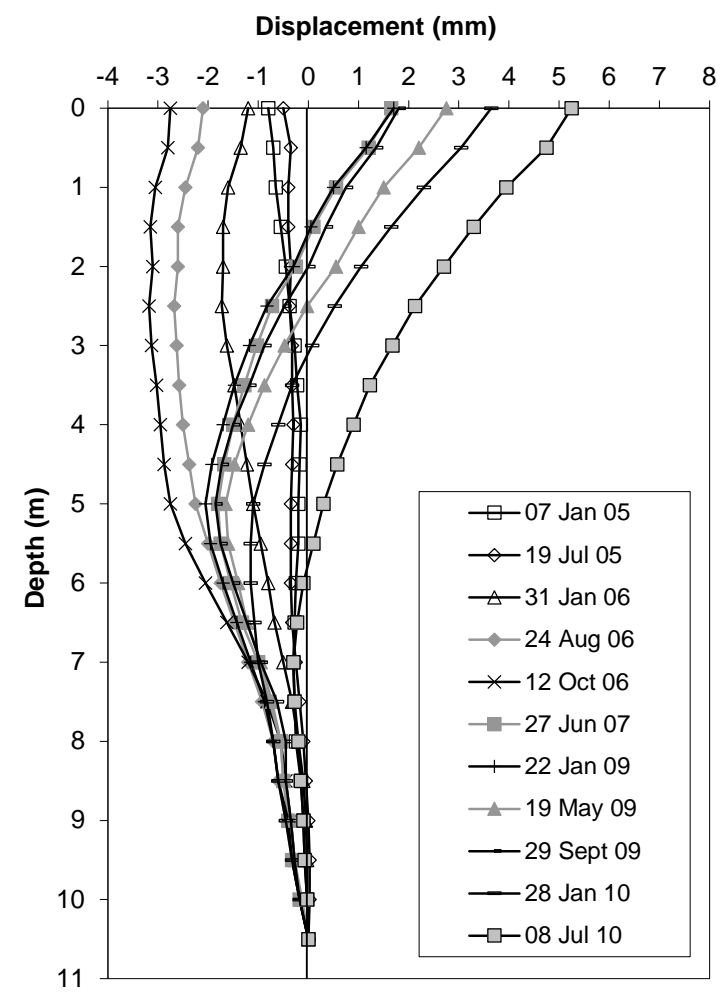

(c)

Fig. 6: Pile inclinometer displacements: (a) Pile A; (b) Pile B; and (c) Pile C. Downslope displacements are denoted positive. 


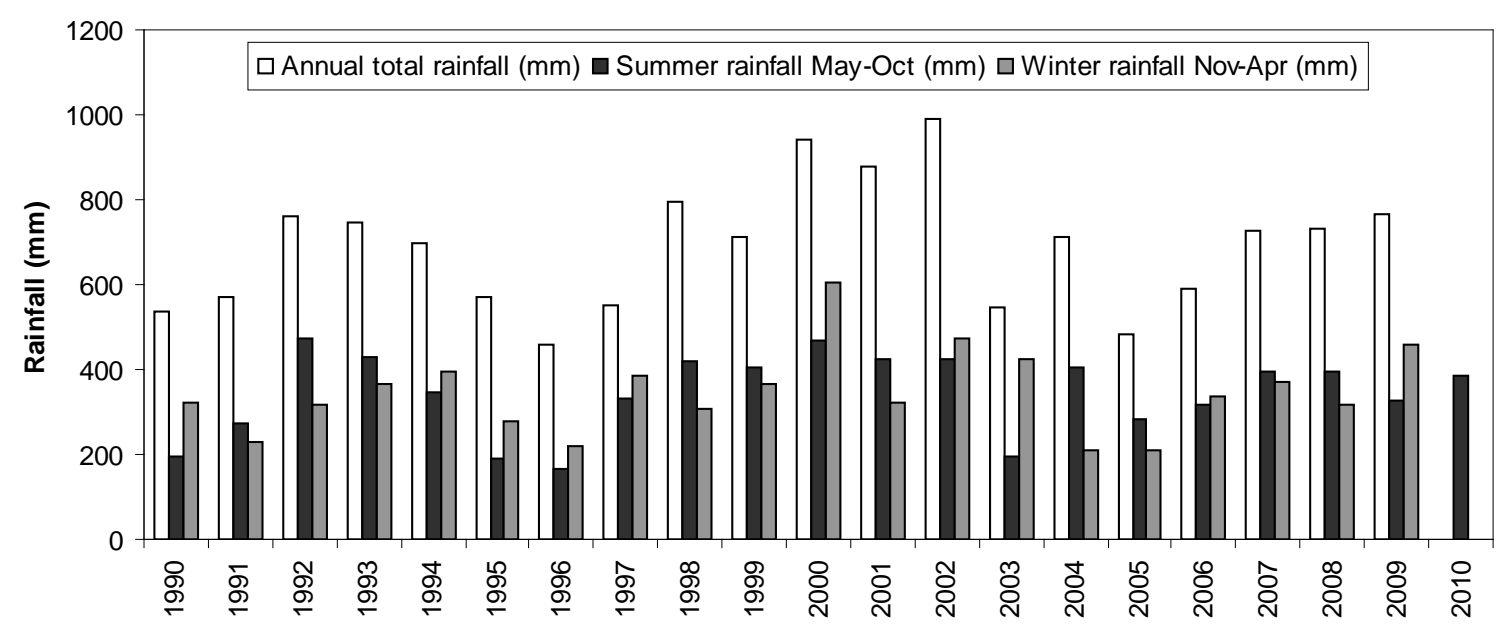

(a)

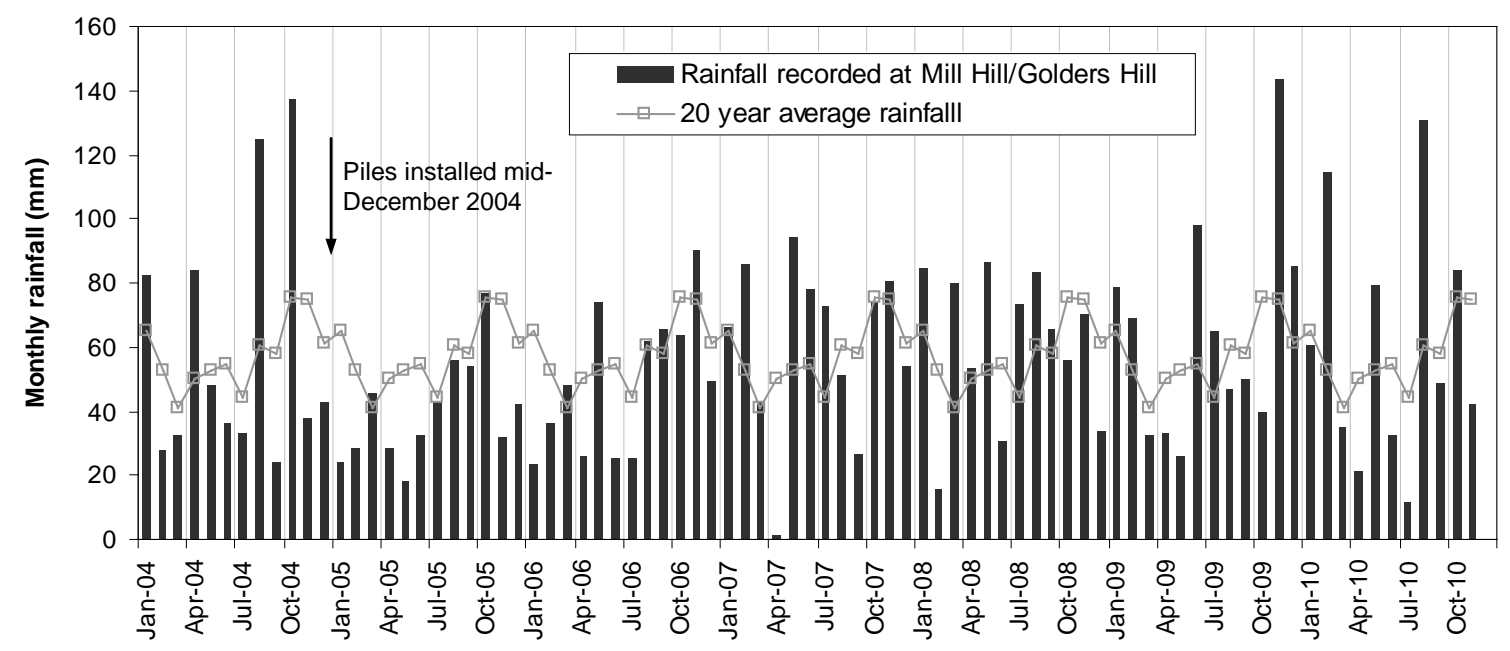

(b)

Fig. 7: Rainfall recorded at the Mill Hill site from December 2004 to March 2007, and at Golders Hill, $4.5 \mathrm{~km}$ from the site, for the remainder of the periods shown: (a) annual and 6-month totals 1990-2010; and (b) monthly totals 2004-2010. 


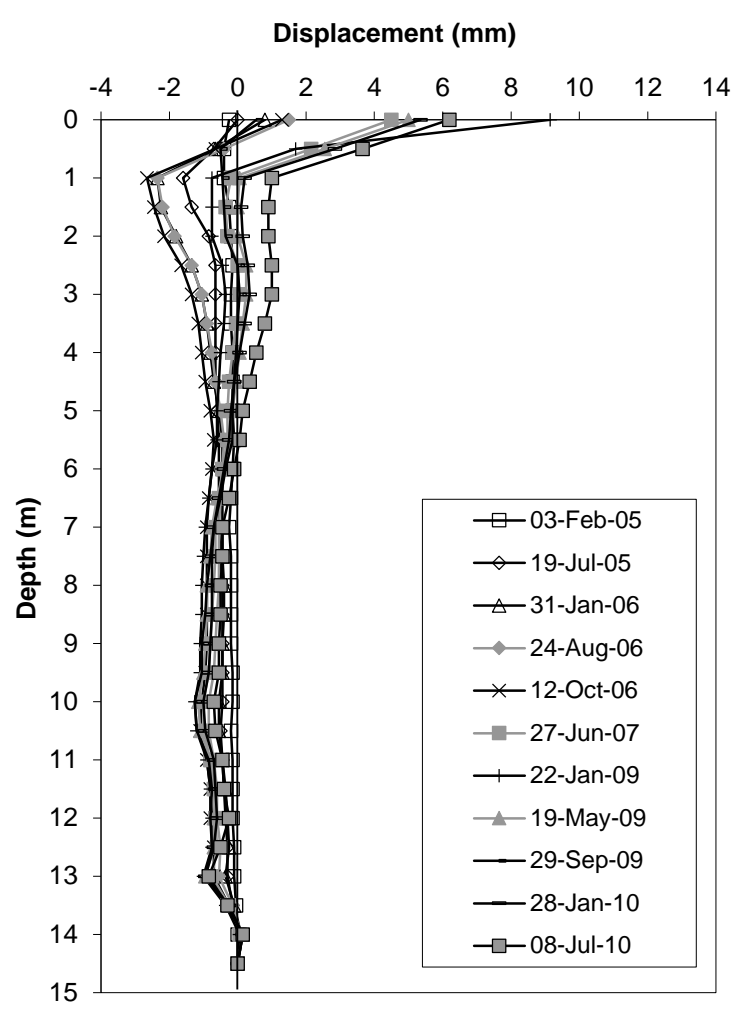

(a)

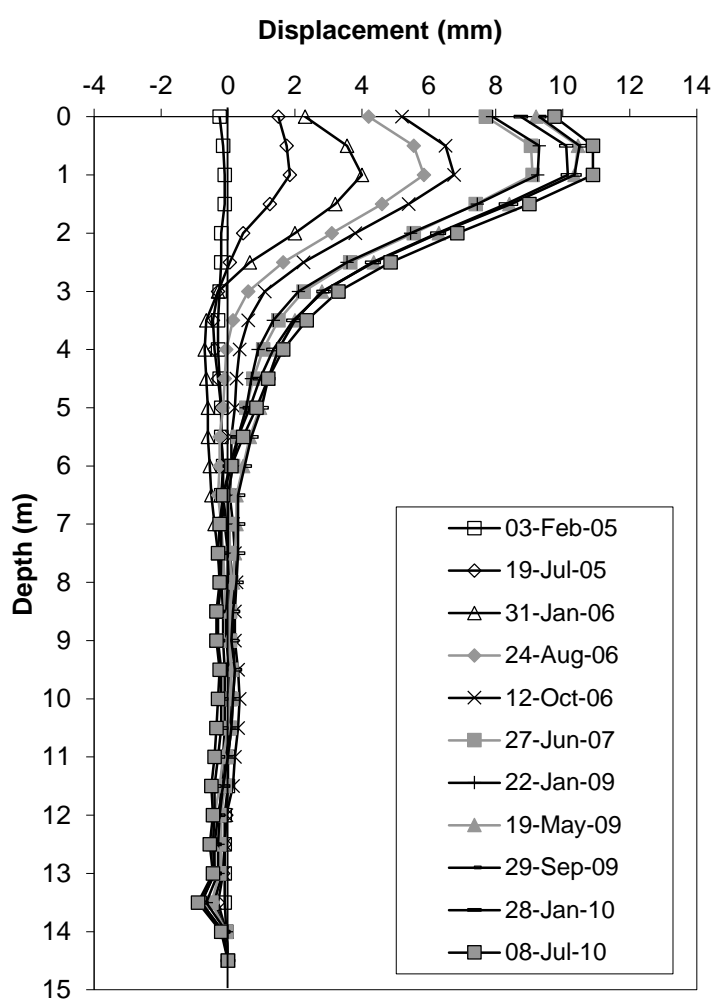

(b)

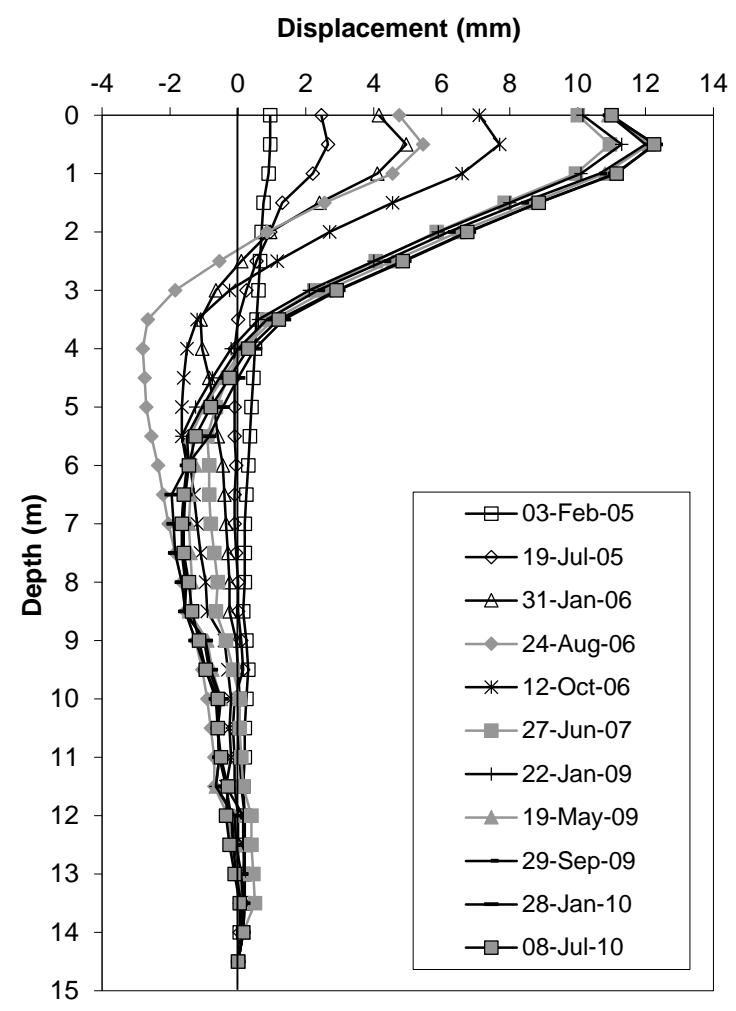

(c)

Fig. 8: Slope inclinometer displacements: (a) tube b; (b) tube c; and (c) tube d. Downslope displacements are denoted positive. 


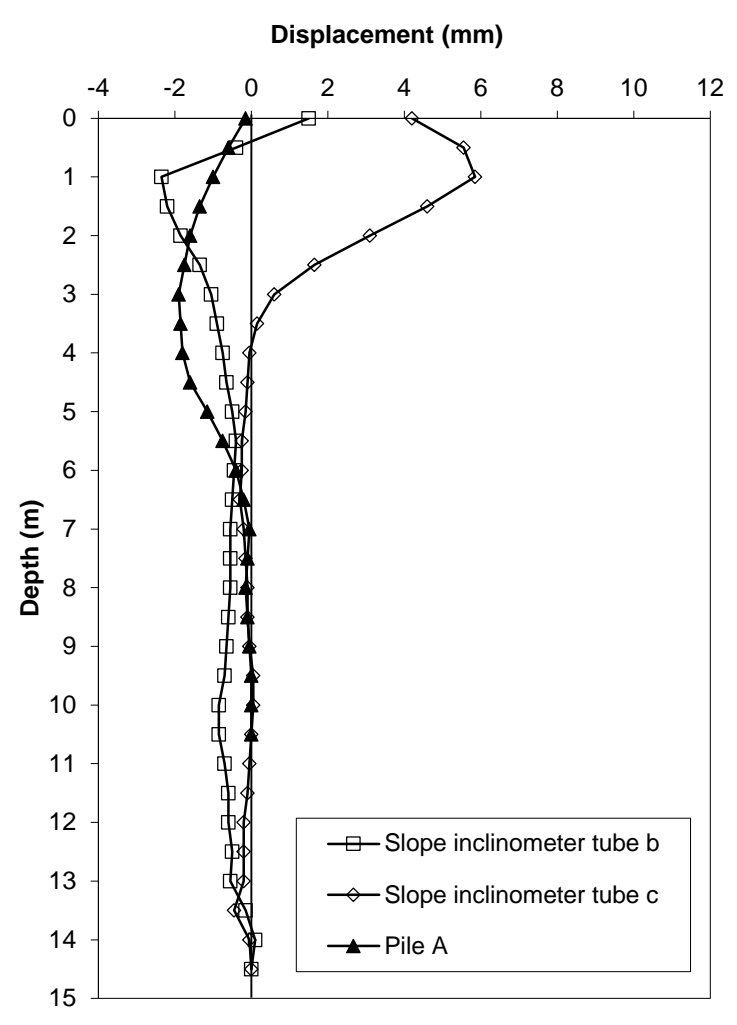

(a)

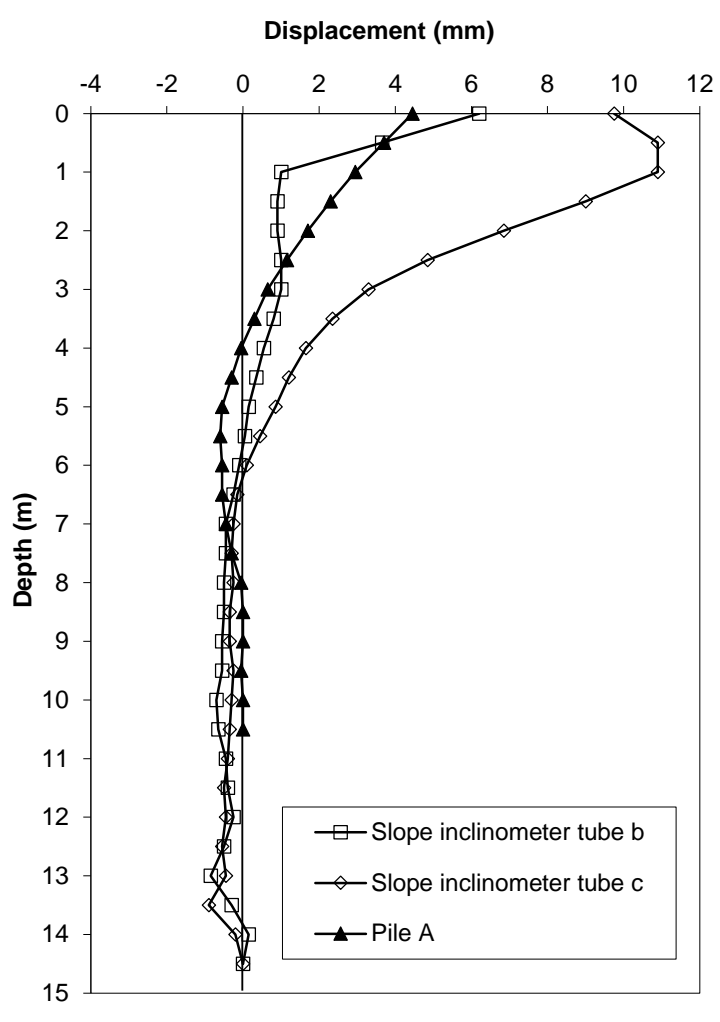

(b)

Fig. 9: Comparison of displacements measured by Pile A, and slope inclinometer tubes b and c, immediately upslope and downslope of Pile A: (a) 24 August 2006 (20 months after installation of instruments); and (b) 08 July 2010 (66 months after installation). 


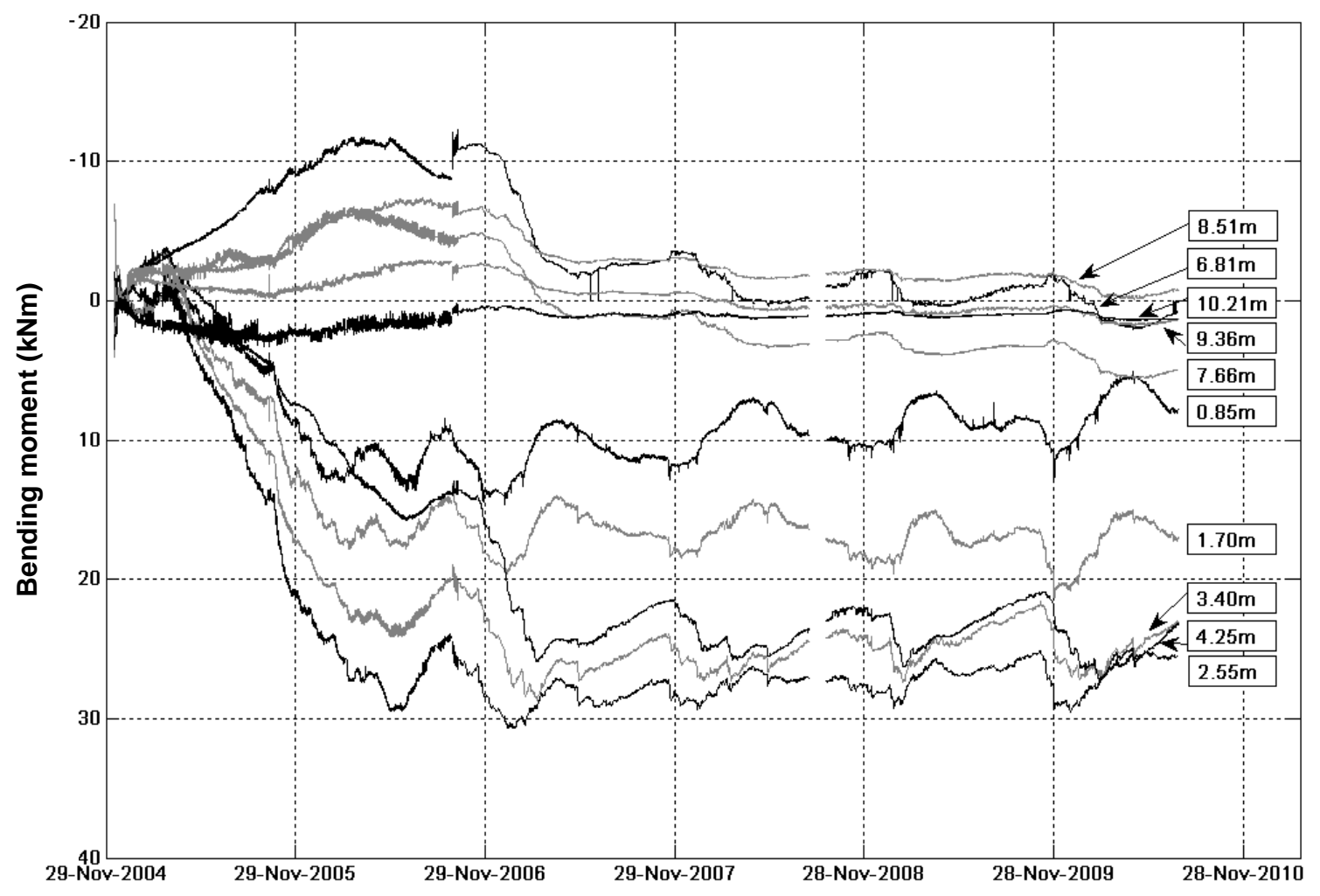

(a)

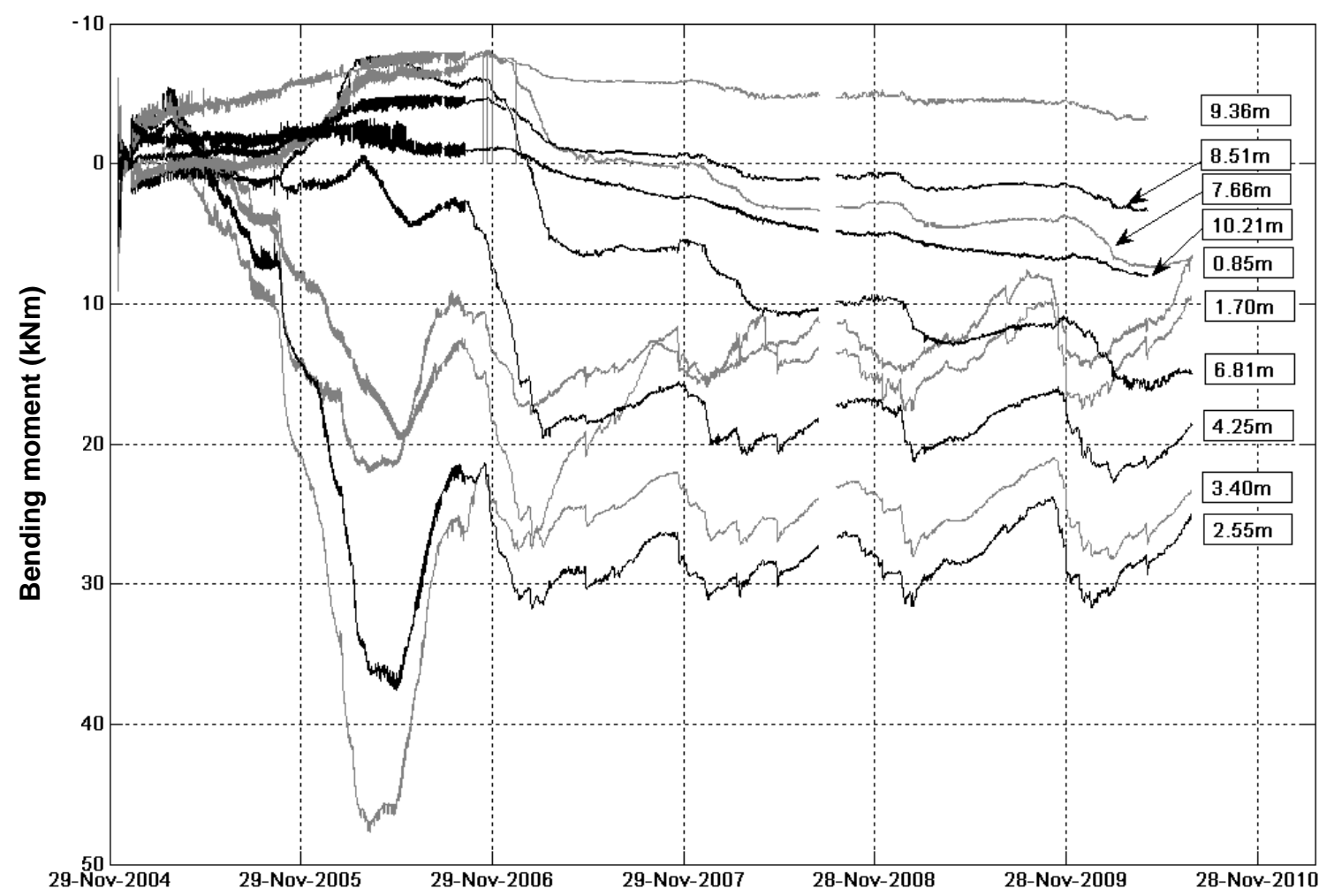

(b)

Fig. 10: Bending moment plotted against time (a) Pile B; and (b) Pile C. 


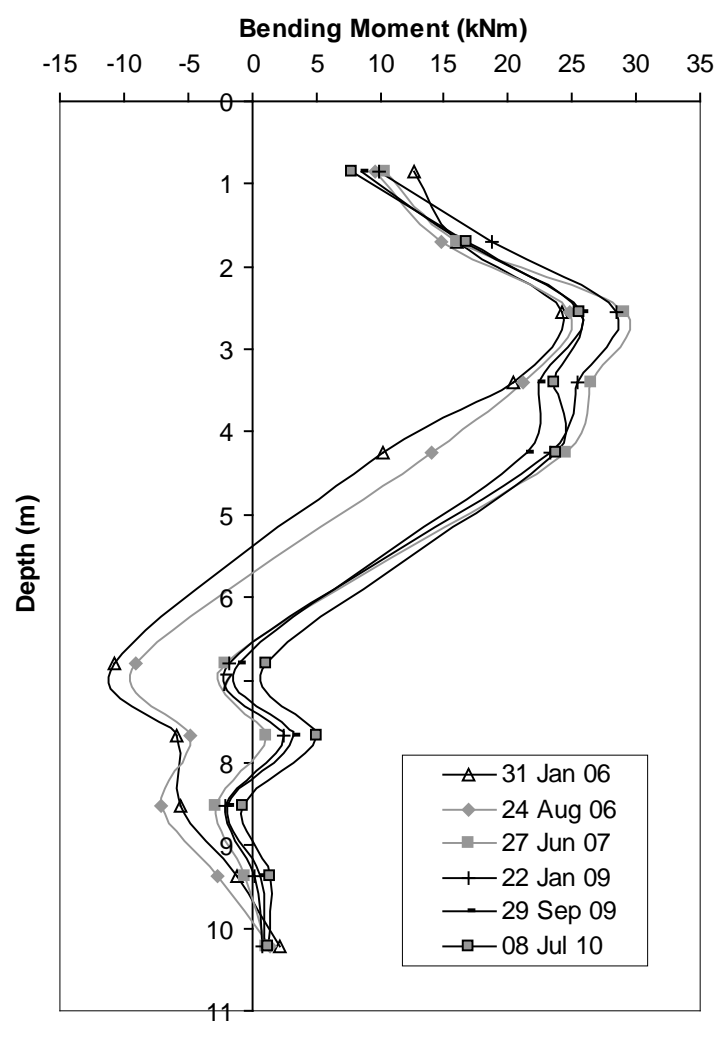

(a)

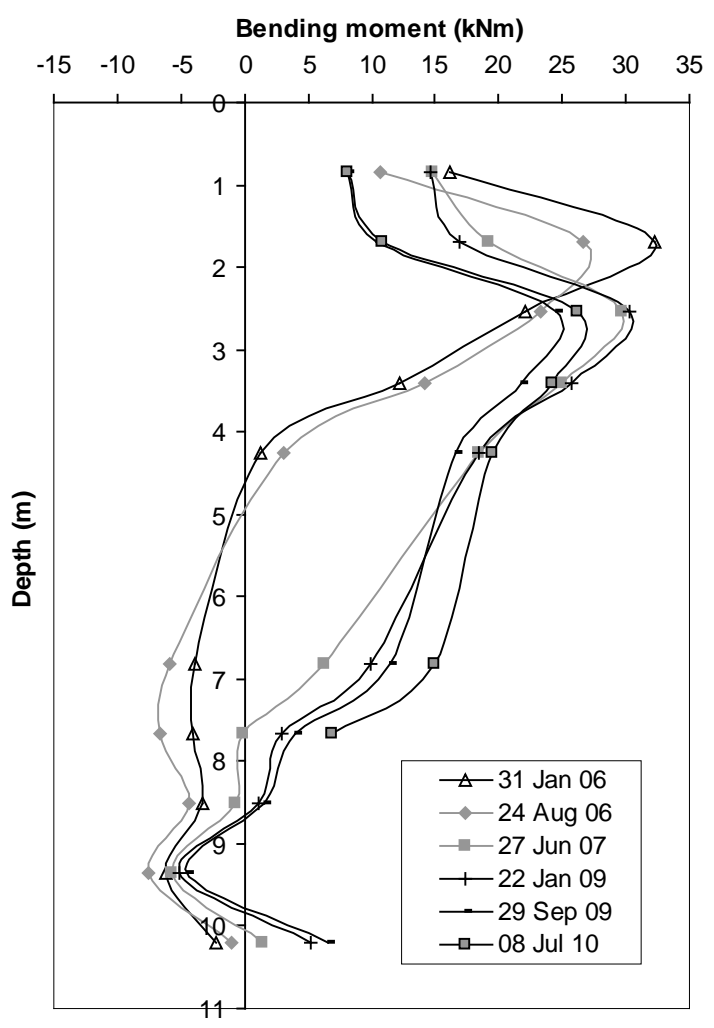

(b)

Fig. 11: Bending moment plotted against depth (a) Pile B; and (b) Pile C. 


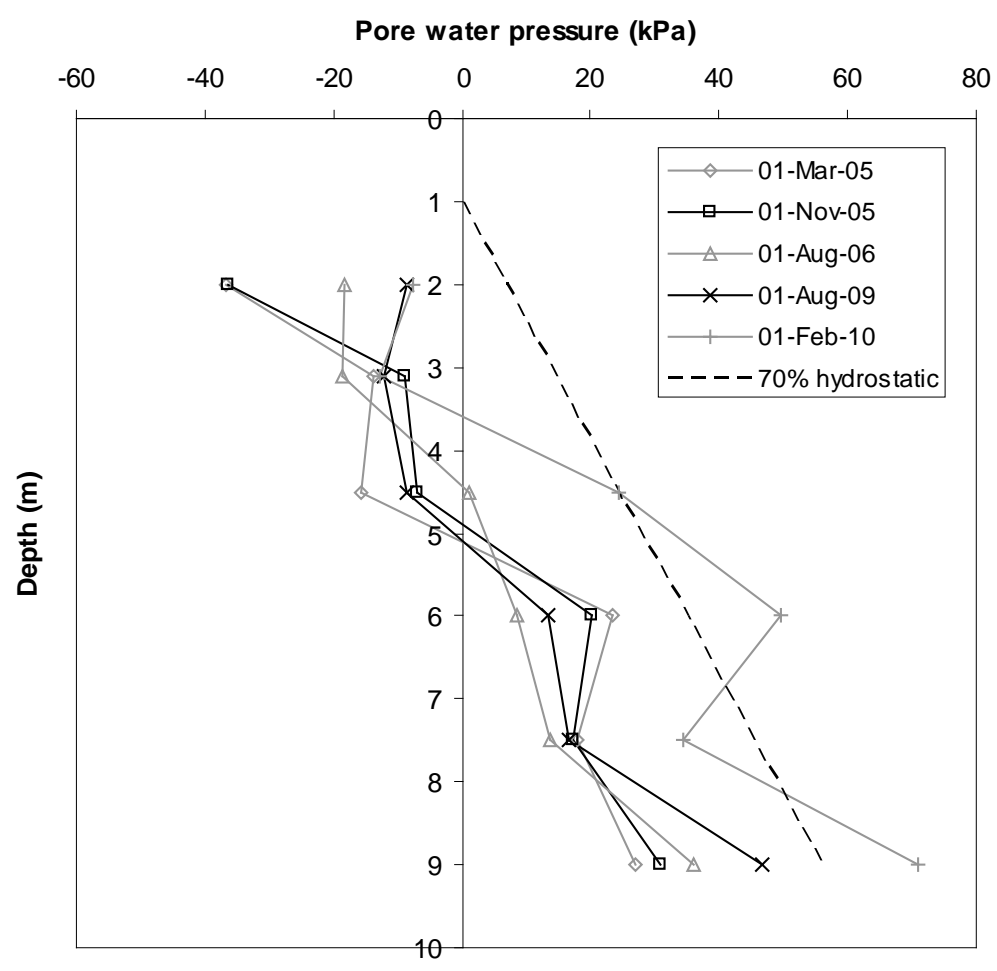

Fig. 12: Profiles of pore water pressure measured by piezometers installed from the front edge of the berm. 


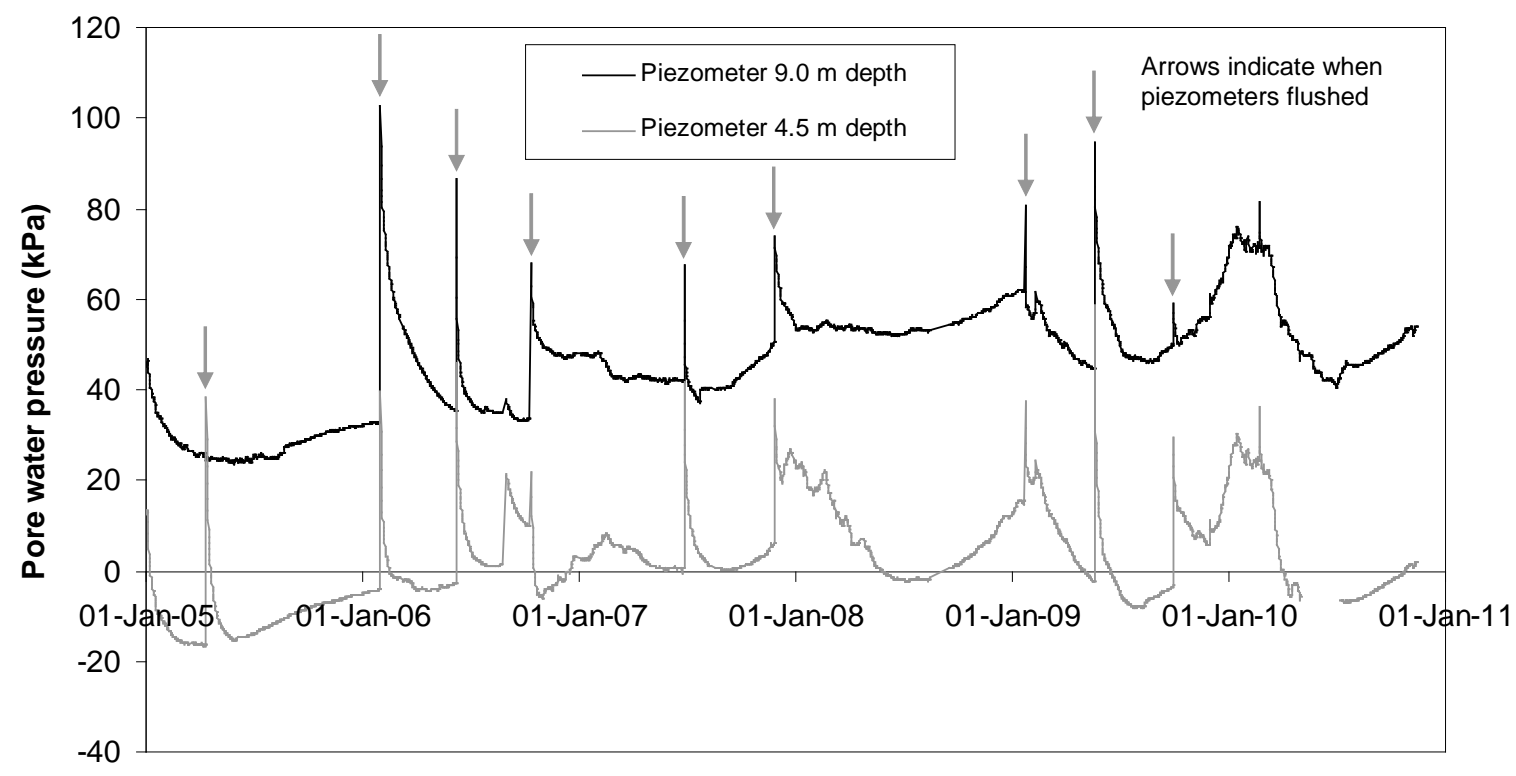

(a)

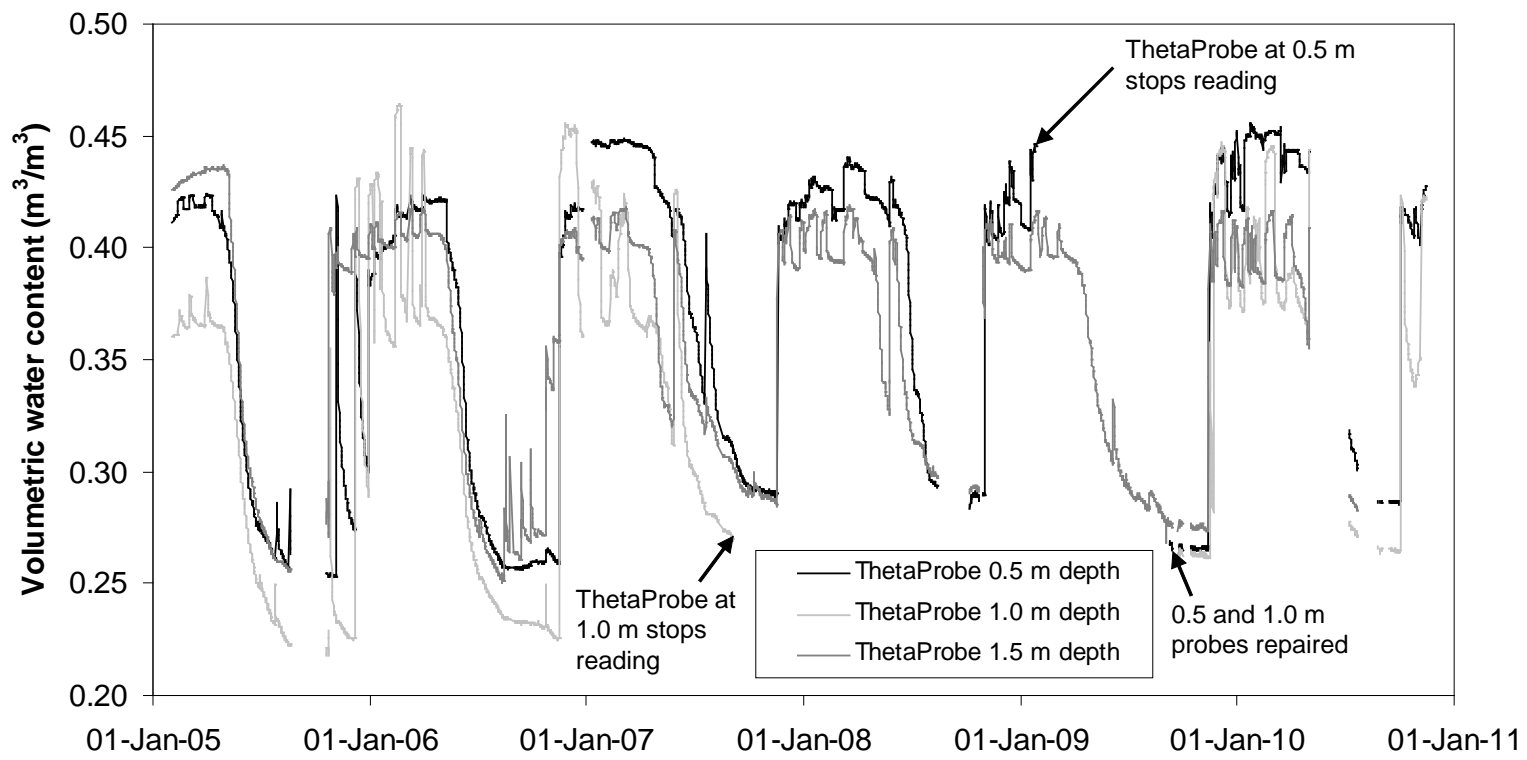

(b)

Fig. 13: (a) pore water pressures plotted with time for select piezometers installed in the clay slope from the front edge of the berm structure; and (b) water content plotted with time measured using TDR ThetaProbes installed in the clay slope just upslope of the berm. The spikes in the readings in (a) indicate when the piezometers were flushed (i.e. had water circulated through them to remove any presence of air). It then takes a few days for the device to come back into equilibrium with the water pressures in the soil. 


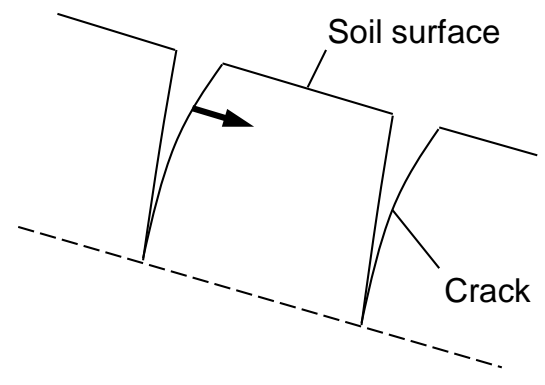

(a)

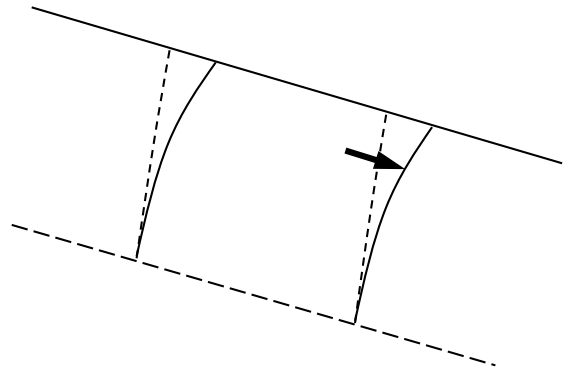

(b)

Fig. 14: Postulated mechanism of surface downslope movement in which deep desiccation cracks: (a) open during summer in the downslope direction, and (b) close during winter, also in the downslope direction. (Note that movements of the individual crack faces on opening and closing may not both be in the downward direction as idealised here, but the net movement after crack opening and closing would be downslope). 


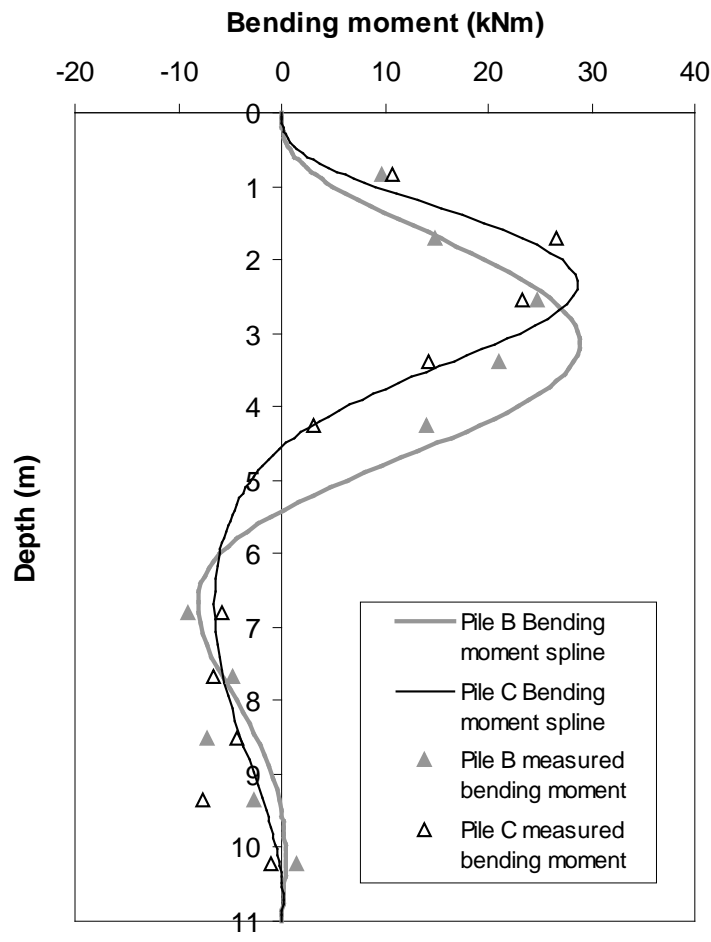

(a)

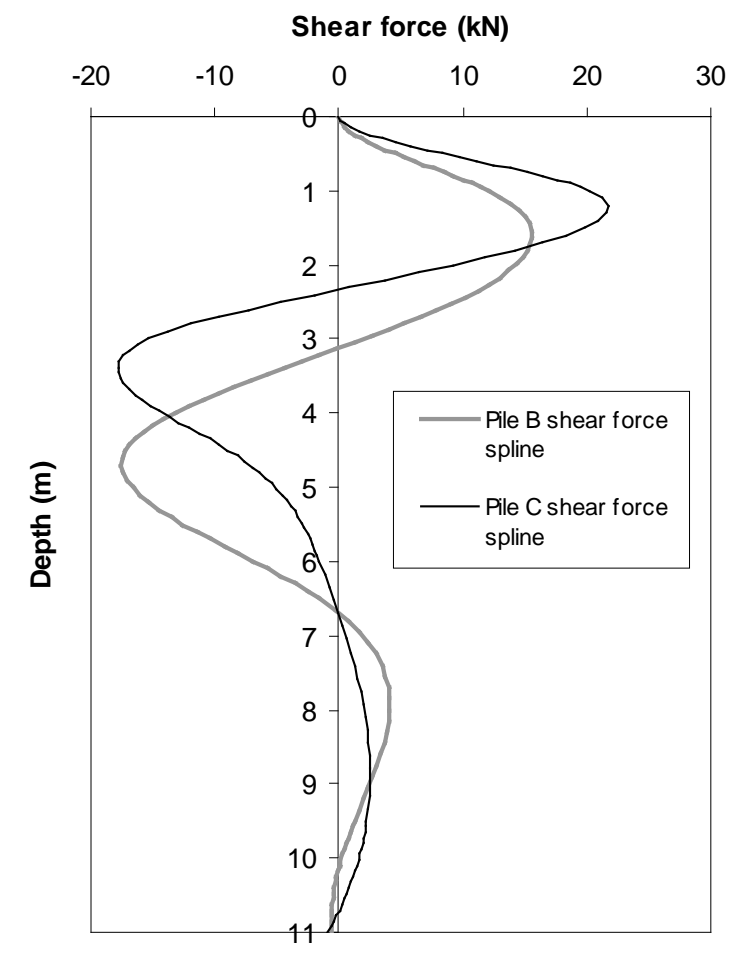

(c)

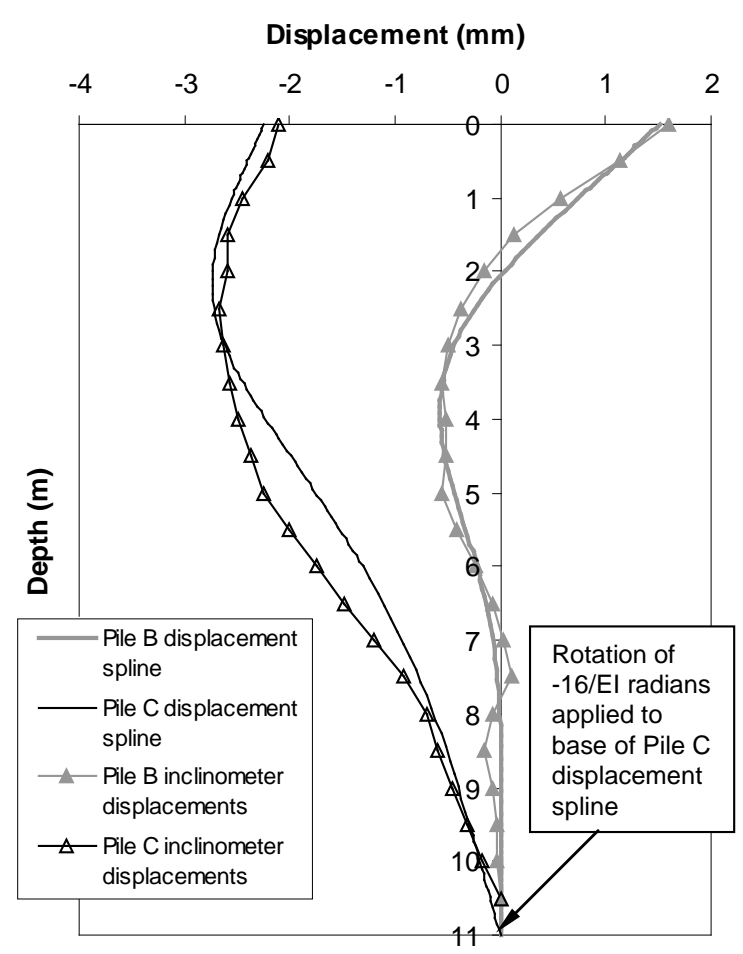

(b)

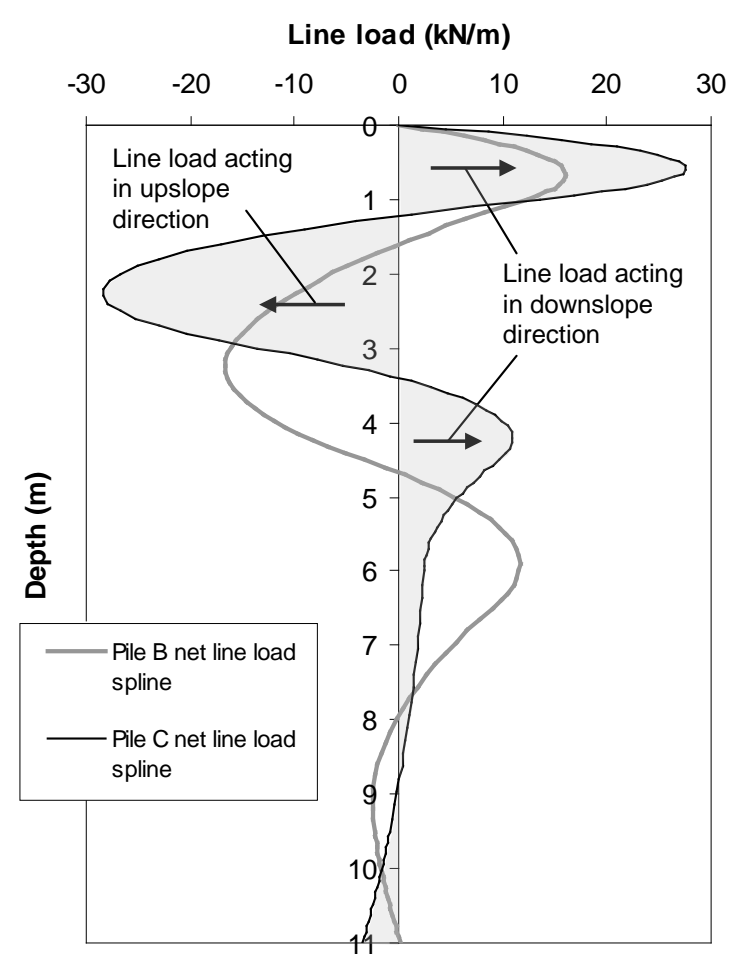

(d)

Fig. 15: Splines fitted to measured pile bending moments for Piles B and C for 24 August 2006: (a) splines fitted to the measured bending moment from the strain gauges; (b) displacement splines and measured inclinometer displacements; (c) shear force obtained by differentiating the splines in (a); and (d) net line load profile obtained by twice differentiating the splines in (a). 


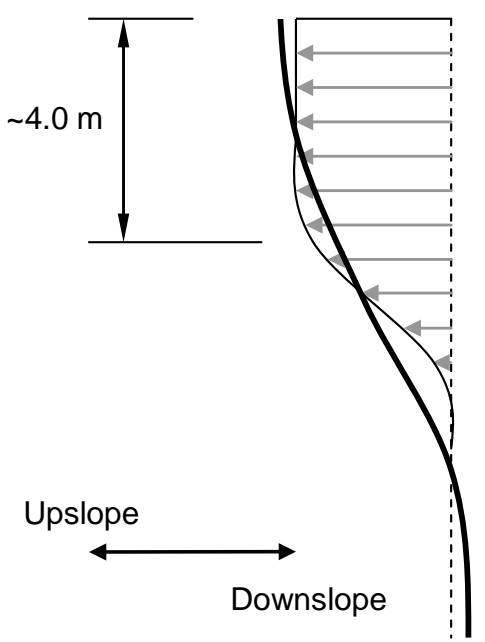

(a)

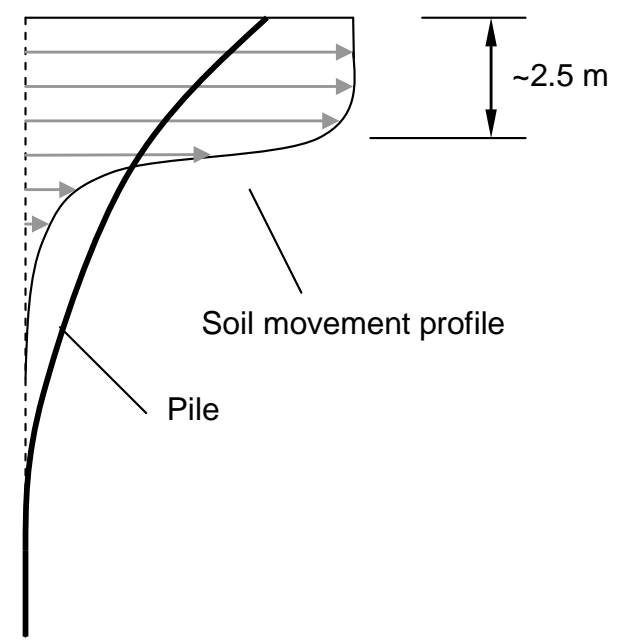

(b)

Fig. 16: Idealised pile-soil interaction mechanisms: (a) upslope displacements of piles due to embankment shrinkage within the tree rooting zone; and (b) downslope displacements of piles due to surface instability. 


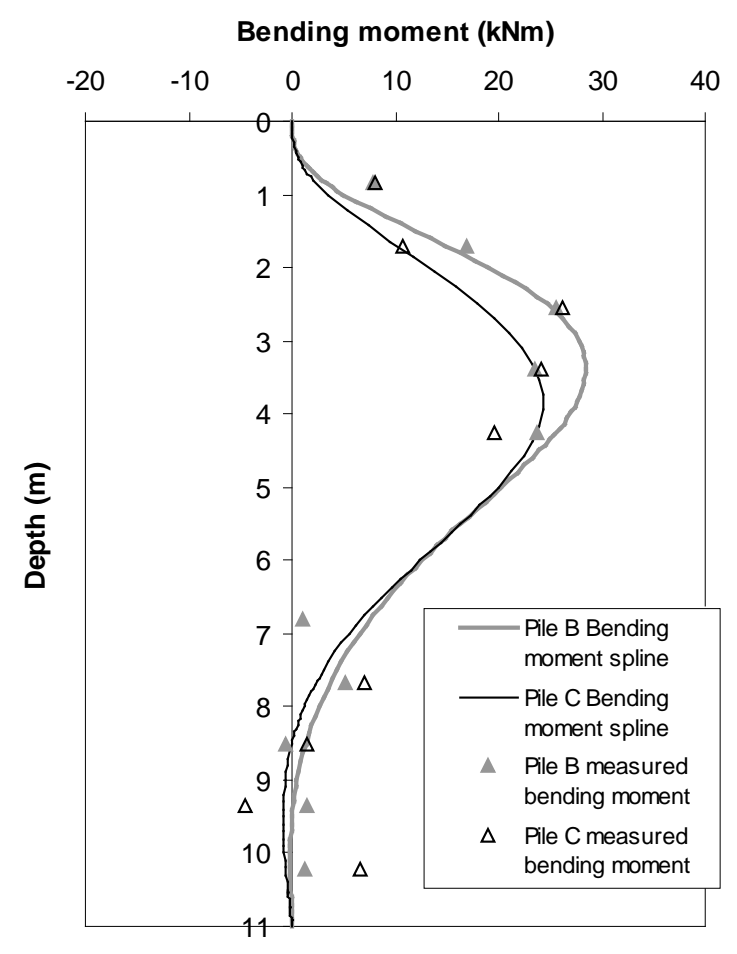

(a)

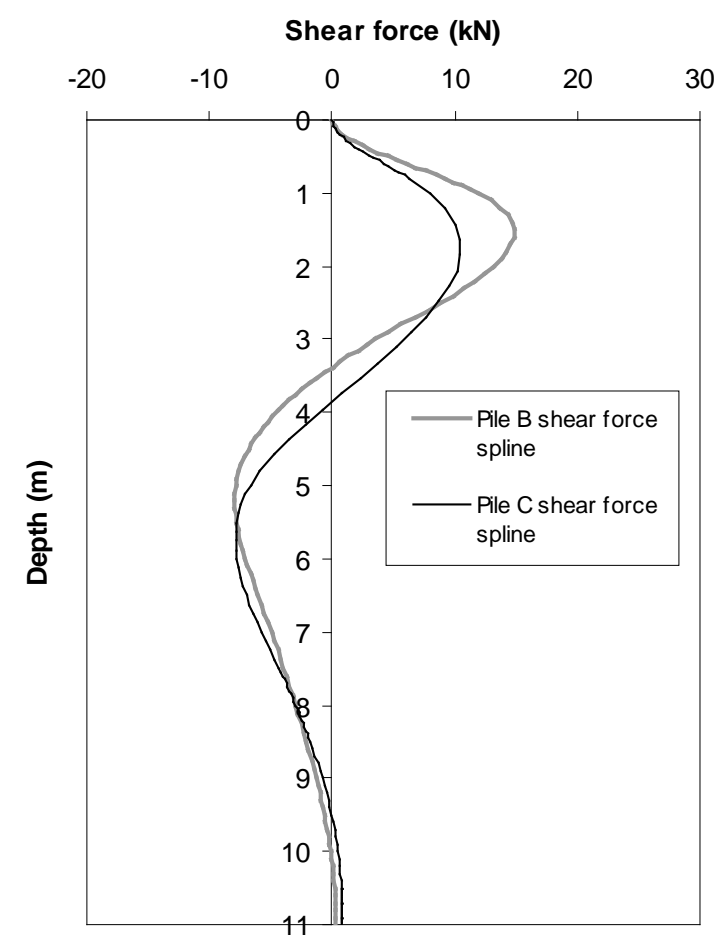

(c)

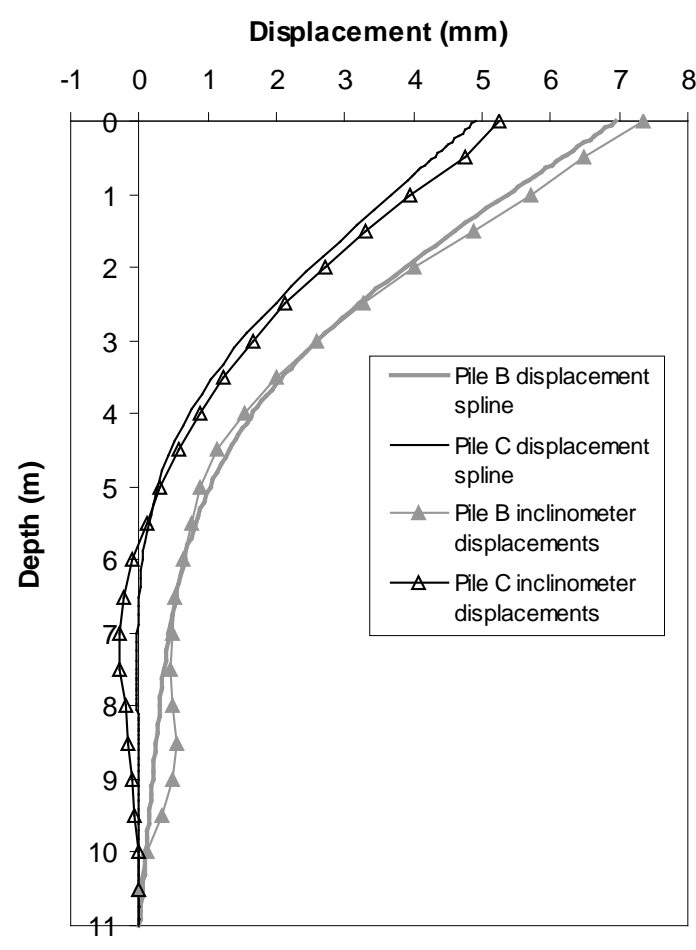

(b)

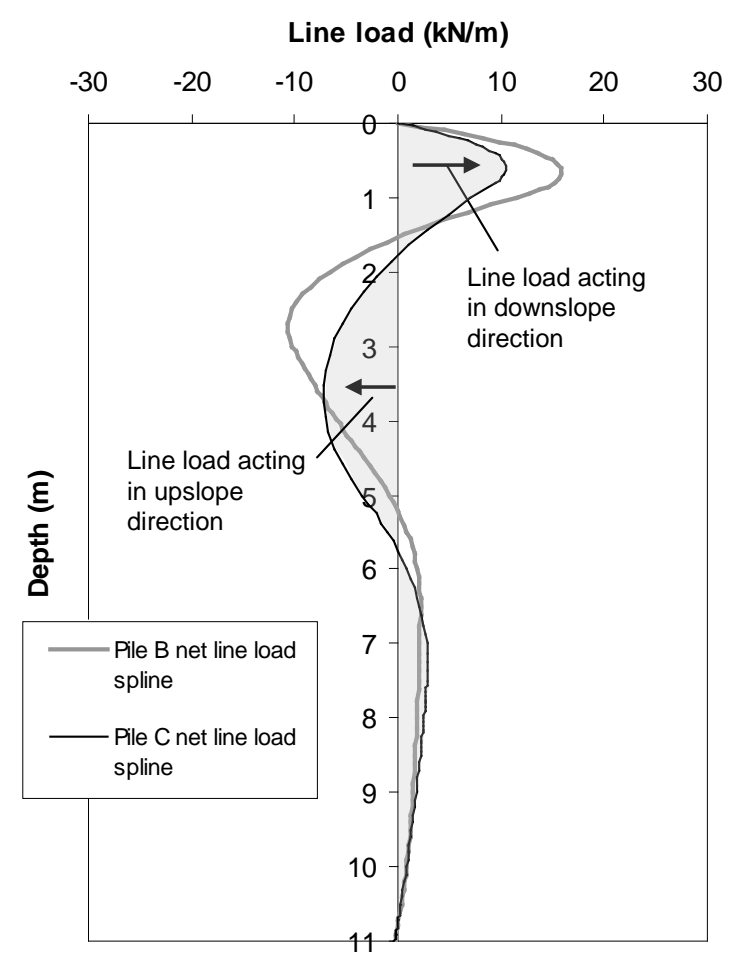

(d)

Fig. 17: Splines fitted to measured pile bending moments for Piles B and C for 10 July 2010: (a) splines fitted to the measured bending moment from the strain gauges (note bottom three gauge readings for Pile $\mathrm{C}$ are taken from when the gauges last functioned in early 2010); (b) displacement splines and measured inclinometer displacements; (c) shear force obtained by differentiating the splines in (a); and (d) net line load profile obtained by twice differentiating the splines in (a). 


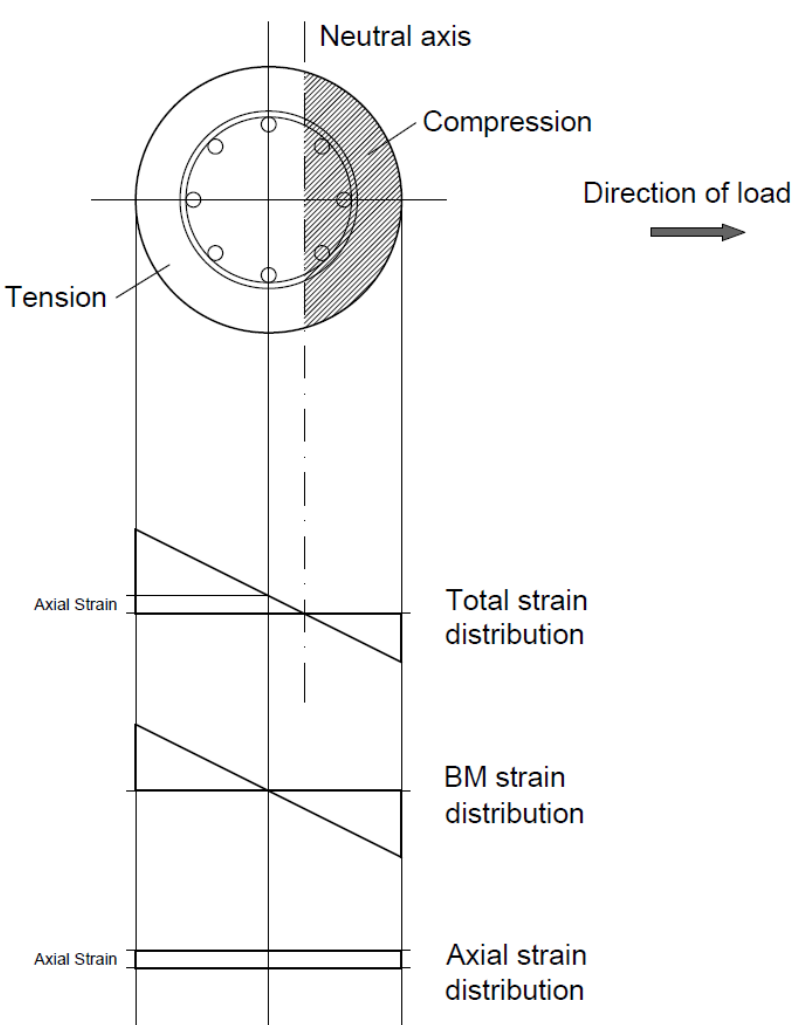

(a)

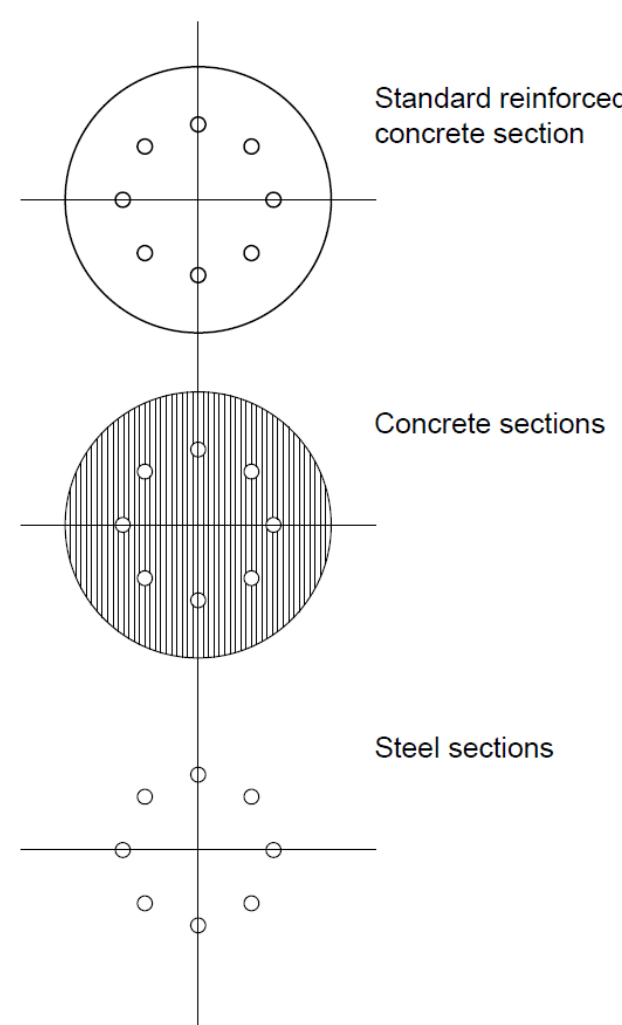

(b)

Fig. 18: (a) Distributions for bending and axial strain through a pile assuming an uncracked section; (b) concrete and steel sections used in the calculation of bending moment. 